\title{
An Analysis of Next Generation Access Networks Deployment in Rural Areas
}

\author{
Claudio Feijóo \\ CeDInt - Technical University of Madrid, Spain \\ cfeijoo@.cedint.upm.es \\ José-Luis Gómez-Barroso \\ National University for Distance Learning
}

\author{
Madrid, Spain \\ jlgomez@cee.uned.es \\ Sergio Ramos \\ CeDInt - Technical University of Madrid, Spain \\ sramos@cedint.upm.es
}

\begin{abstract}
Next generation access networks (NGAN) will support a renewed electronic communication market where main opportunities lie in the provision of ubiquitous broadband connectivity, applications and content. From their deployment it is expected a wealth of innovations. Within this framework, the project reviews the variety of NGAN deployment options available for rural environments, derives a simple method for approximate cost calculations, and then discusses and compares the results obtained. Data for Spain are used for practical calculations, but the model is applicable with minor modifications to most of the rural areas of European countries. The final part of the paper is devoted to review the techno-economic implications of a network deployment in a rural environment as well as the adequacy and possible developments of the regulatory framework involved.
\end{abstract}

Keywords: next generation networks, fibre, mobile communications, $4 \mathrm{~g}$, electronic communications regulation

\section{BACKGROUND}

The so-called Next Generation Networks (NGN) will be the supporting infrastructure of ubiquitous ultra-broadband. For the purposes of this paper, a NGN will be a single network which delivers multiple data applications -whether originally based on voice, data, and video- to multiple devices -whether fixed or mobile. In addition, it will be considered that the provision of services is decoupled from networks. The choice of access technology is simply a matter of costs (which in turn depend basically on demographic and geographic variables), possible re-use of existing infrastructures and the user's requirements (and expectations). The access part of a NGN is usually called Next Generation Access Networks (NGAN).

Precisely, the conditions for the deployment of NGAN are currently on the forefront of the debate about the role of telecommunication market developments, the best regulation for them and the level and modes of potential public involvement. In broad terms it can be said that we are currently in a very early stage of NGAN deployment - particularly out of main urban areas. This situation is influenced by relatively unknown technology roadmaps, possibly some doubts about the implementation of the regulatory scenario, as well as, especially, the economic uncertainties about the return on investments.

From the perspective of techno-economics, there is not a one-size-fits-all NGAN: the most suitable type of NGAN depends heavily on the re-use of existing infrastructures and on the type of geo-demographic area (the "geotype"). Indeed, operators invest in areas that are profitable. As dense areas are more profitable than rural ones, dense areas will be served first. If we consider geographic density as a continuum, there is a point where operators stop investing because it is no longer profitable. In fact, in most rural areas low population density and high deployment costs discourage private investments, creating a negative feedback of limited capacity, high prices, and low service demand.

As the profitability of any area depends basically on infrastructure costs, which tend to decrease slowly over time, there are some possibilities of less dense areas to become profitable as time passes by [1], all other parameters equal. However, this effect could be too slow and meanwhile it would impact significantly on equity in territorial terms for a potential long period of time. In fact, currently there is little or no commitment to connect areas that include smaller towns and rural villages [2]. Data collected by OECD have shown that, among the developed countries, those with a large urban population such as South Korea, Japan, France and the Netherlands are more likely to achieve a higher rate of broadband penetration than those with significant rural communities such as the United States and Canada [3].

Therefore, it is necessary to analyse the more suitable choices for NGAN deployments in these areas, depicting and accurate scenario of related deployment costs. This is the main objective of this paper. For this, a simple method for cost calculations will be derived using the data for Spain for reasons of availability. However, it would be applicable to most of the rural areas of European countries. Based on the results obtained, the techno-economic implications of NGAN deployments in rural areas will be reviewed as well as the adequacy and possible developments of the existing EU regulatory framework. 


\section{GEOTYPES IN THE RURAL SCENARIO}

The assumptions on geotypes for network deployment consider a classification in zones based on population density as the basic parameter affecting the cost of rolling out a NGAN. This is the most used approach to network deployment cost calculations, see for instance Analysis Mason [4].

For the particular case of Spain, a division into 10 different zones (numbered I to X) has been chosen. See Annex for a detailed description of the main parameters for the geotypes used in the calculations. Apart from the direct relevance of the case of Spain as a main European instance for NGAN deployment, it is interesting to note that data for Spain are relatively similar to the Euroland scenario [5]. The population in this area adds up to 46.4 million inhabitants, which is the mean of seven European states: France, Germany, Italy, Holland, Spain, Sweden and the United Kingdom. Demographically, Euroland is made up by a few urban areas with a high population density, a greater number of suburban areas, many rural areas and very few remote areas. Last, there are 15.4 million households in Euroland and, of the total inhabitants, 17.3 million are employed in 3.2 million companies.

It is also worth to note that previous studies usually considered 3 to 7 zones. For instance, in the Euroland scenario [5] it was assumed that $50 \%$ of the population lived in urban areas $(6,000$ inhab/km2 population density), $35 \%$ in suburban areas (500 inhab/km2 density) and around $15 \%$ in rural areas (30 inhab/km2 density). Gómez-Barroso and Robles-Rovalo [6] chose a division into 7 zones for WiMAX calculations in México, including rural areas. This is also the number used in Jeanjean [1] for NGAN calculations. Analysis Mason [7], apart from London, also selected 7 zones for its study on fibre deployment in the UK, however leaving aside the rural and remote areas. The motivation for using 10 different zones lies in enjoying more precise estimations in the "grey" areas that the competitive market providers could reach in the medium term as a function of technology, demand and public policies. In fact in the case of Spain about one quarter of the population lives in the $500-100$ inhabitants $/ \mathrm{Km}^{2}$ area, where the population density typical of suburban zones finishes and the rural type-ofdensity begins. Also in Spain, about $46 \%$ of the population lives in urban areas (above 1000 inhabitants $/ \mathrm{Km}^{2}$ ), with an additional $10 \%$ in lower-density suburban areas. Remote rural areas (below 50 inhabitants $/ \mathrm{Km}^{2}$ ) made up $12 \%$ of the population, but $77 \%$ of the territory.

However, the main drawback of a classification based on population density is the lack of information on buildings clustering, mainly for suburban and rural areas. Therefore, to enhance the modelling of the deployment costs, each of the zones has been divided into two types, (a) and (b), resulting in a total of 18 geotypes for the calculations (in zones IX and X the population density is so low that all population is assumed to be distributed according to the $\mathrm{b}$ model). Looking from the perspective of network deployment, the key element for this additional categorisation is the location of the local exchange, cable headend or base station. For instance, exchanges tend to cover the central core of a settlement and, at the same time, some wider areas where the settlement is sparser [4], see Fig. 1.

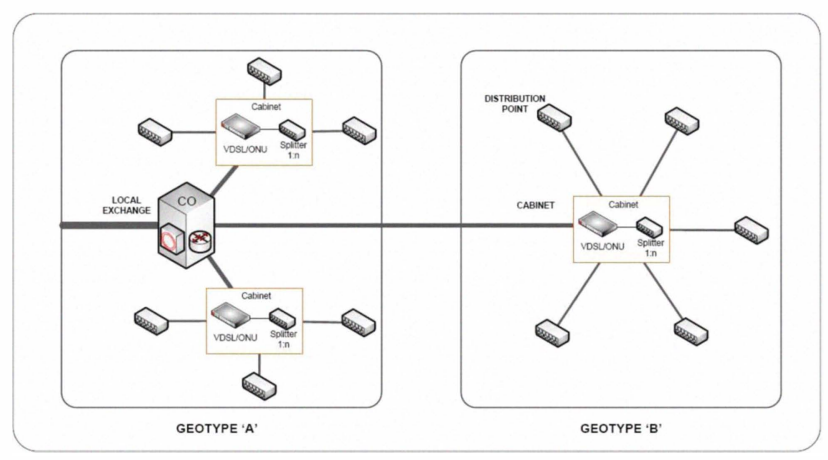

Figure 1. Geotypes a) premises close to the local exchange, and b) premises sparse and far from the local exchange. Source: adapted from Analysis Mason [4]

The share of potential subscribers (inhabitants, households and businesses) among these two geotypes has been calculated using 5 prototypical municipalities (those closer to the average population and surface) for each of the zones. In each of these municipalities it has been possible to obtain the percentage of surface for dense urban ${ }^{1}$ and scattered urban and suburban $\operatorname{areas}^{2}$ using data from Spanish Housing Ministry [8]. The resulting population-weighted average has been regarded as representative of the situation in each of the zones.

\section{TECHNOLOGIES FOR RURAL DEPLOYMENT OF NGAN}

In general, broadband access technologies are classified by the physical medium in two major groups: wired -or fixed linetechnologies and wireless technologies. The main wired technologies are based on fibre, coaxial, copper wire and power line. In the following we will consider the first three of them, leaving aside power line due to its low implantation and weak mass market prospects ${ }^{3}$. When classifying wireless technologies two main sets of characteristics are considered: being terrestrial or satellite-based and being fixed wireless or mobile wireless. Due to the requisites of NGAN - very high bandwidth for each user- only the terrestrial solutions will be considered in the following ${ }^{4}$.

${ }^{1}$ When more than $80 \%$ of the surface is covered with buildings and roads.

${ }^{2}$ When the surface is covered with buildings and roads associated with areas of vegetation or land occupying between $30-80 \%$ of the total surface.

${ }^{3}$ However it is widely used in the home environment and as part of the smart power grids concept, for further details see, for example, [9] N. Pavlidou, et al., "Power Line Communications: state of the art and future trends," IEEE Communications Magazine, vol. 41, pp. 34-40, 2003.

${ }^{4}$ For the sake of comparison, according to Eutelsat the next generation of satellites at Ka-band (scheduled to be launched in 2011) will provide 35 times more throughput than traditional $\mathrm{Ku}-$ band satellites, will use spot beam technology, and it will be able to provide typically dedicated coverage in 80 set areas delivering shared downstream speeds of $10 \mathrm{Mb} / \mathrm{s}$ and $2 \mathrm{Mb} / \mathrm{s}$ upstream to users in those areas. 
Each of technologies considered for the study has its advantages and disadvantages in terms of maximum bandwidth/transmission speed, reliability, cost of deployment and ease of coverage. Therefore there is not an obvious choice for all situations, and in practice a telecommunications operator will likely use a "mix" of technologies, as later discussed. Table I overviews some of the main milestones and features of the technologies involved in the deployment of NGAN compiled by the authors from publicly available industry data and forecasts.

TABLE I. MAIN FEATURES OF POTENTIAL NGAN TECNOLOGIES FOR RURAL DEPLOYMENT

\begin{tabular}{|c|c|c|c|c|}
\hline \multirow[b]{2}{*}{ Features } & \multicolumn{4}{|c|}{ NGAN Technology } \\
\hline & $\begin{array}{l}\text { FTTH } \\
\text { GPON }\end{array}$ & $\begin{array}{l}\text { FTTC } \\
\text { FTTB } \\
\text { VDSL }\end{array}$ & $\begin{array}{c}H F C \\
\text { DOCSIS } 3.0\end{array}$ & $\operatorname{LTE}(4 G)$ \\
\hline $\begin{array}{l}\text { Theoretical } \\
\text { max. data } \\
\text { rates }\end{array}$ & $\begin{array}{l}2,50 \mathrm{~Gb} / \mathrm{s}^{\mathrm{a}} \\
\text { (downstr.) } \\
1,25 \mathrm{~Gb} / \mathrm{s} \\
\text { (upstream) }\end{array}$ & $\begin{array}{c}100 \mathrm{Mb} / \mathrm{s} \\
\text { (downstr.) } \\
50 \mathrm{Mb} / \mathrm{s} \\
\text { (upstream) }\end{array}$ & $\begin{array}{c}400 \mathrm{Mb} / \mathrm{s} \\
\text { (downstr.) } \\
100 \mathrm{Mb} / \mathrm{s} \\
\text { (upstream) }\end{array}$ & $\begin{array}{c}300 \mathrm{Mb} / \mathrm{s} \\
\text { (downstream) } \\
75 \mathrm{Mb} / \mathrm{s} \\
\text { (upstream) }\end{array}$ \\
\hline $\begin{array}{l}\text { Typical } \\
\text { data rates } \\
\text { per user }\end{array}$ & $\begin{array}{l}100-250 \\
\mathrm{Mb} / \mathrm{s}(\mathrm{d}) \\
50-100 \\
\mathrm{Mb} / \mathrm{s} \mathrm{(u)}\end{array}$ & $\begin{array}{c}\text { 30-50 Mb/s } \\
\text { (downstr.) } \\
5-15 \mathrm{Mb} / \mathrm{s} \\
\text { (upstream) }\end{array}$ & $\begin{array}{c}50 \mathrm{Mb} / \mathrm{s}^{\mathrm{b}} \\
\text { (downstr.) } \\
10 \mathrm{Mb} / \mathrm{s} \\
\text { (upstream) }\end{array}$ & $\begin{array}{c}1-10 \mathrm{Mb} / \mathrm{s}^{\mathrm{c}} \\
\text { (downstr.) } \\
1 \mathrm{Mb} / \mathrm{s} \\
\text { (upstream) }\end{array}$ \\
\hline $\begin{array}{l}\text { Begin of } \\
\text { massive } \\
\text { deployment } \\
\text { in EU }\end{array}$ & $2009-2012$ & $2007-2010$ & $2009-2011$ & $2011-2013$ \\
\hline $\begin{array}{l}\text { Enhanced } \\
\text { version } \\
\text { max. data } \\
\text { rate }\end{array}$ & $\begin{array}{l}10 \mathrm{G} \text { GPON } \\
10 \mathrm{~Gb} / \mathrm{s}\end{array}$ & $\begin{array}{l}\text { Advanced } \\
\text { DSL } \\
100-300 \\
\mathrm{Mb} / \mathrm{s}\end{array}$ & $\begin{array}{c}\text { DOCSIS } \\
4.0 \\
10 \mathrm{~Gb} / \mathrm{s}\end{array}$ & $\begin{array}{c}\text { LTE } \\
\text { Evolution } \\
1 \mathrm{~Gb} / \mathrm{s}\end{array}$ \\
\hline $\begin{array}{l}\text { Critical } \\
\text { technologies }\end{array}$ & WDMA & ONU & CPE & OFDMA \\
\hline $\begin{array}{l}\text { Main } \\
\text { advantage }\end{array}$ & $\begin{array}{l}\text { Guaranteed } \\
\text { data rates }\end{array}$ & $\begin{array}{c}\text { Re-use of } \\
\text { legacy } \\
\text { network }\end{array}$ & $\begin{array}{l}\text { Re-use of } \\
\text { HFC } \\
\text { network }\end{array}$ & $\begin{array}{l}\text { Evolutionary } \\
\text { from } 3.5 \mathrm{G}\end{array}$ \\
\hline $\begin{array}{ll}\text { Main } & \\
\text { barrier (as } \\
\text { of }\end{array}$ & $\begin{array}{l}\text { Deploy. } \\
\text { cost }\end{array}$ & $\begin{array}{l}\text { Opto- } \\
\text { electronic } \\
\text { equipment }\end{array}$ & $\begin{array}{l}\text { Shared } \\
\text { media }\end{array}$ & $\begin{array}{l}\text { Availability } \\
\text { of devices } \\
\text { Shared media }\end{array}$ \\
\hline
\end{tabular}

c. Depends on number of concurrent users and size of cell

The inclusion of $4 \mathrm{G}$ mobile technologies among NGAN might be controversial. In fact, as a general consideration, wireless technologies are around 3 to 5 years behind fixed ones in terms of data rates per user. However, they are about to reach the $10 \mathrm{Mb} / \mathrm{s}$ level per user with some consistency with peak speeds around $100 \mathrm{Mb} / \mathrm{s}$. As a consequence a number of experts from the industry forecast that mobile broadband connections will overcome fixed ones sometime around 2011-2013 [10-12] and its impact will be considerable from NGAN perspective [13]. To this regard, and in the long run, the massive deployment of femtocells, mobile devices with cognitive radio capabilities and mesh network topologies could make wireless networks almost indistinguishable from most of today's ultrabroadband fixed solutions.

\section{METHODOLOGY}

The methodology for the calculation of the deployment costs for NGAN technologies in rural scenarios departs from a number of assumptions. First, the backbone network will not be included in the calculations ${ }^{5}$. Secondly, legacy networks will be consider where possible to re-use part of the infrastructure previously built by the same or other operators. The model has chosen the parameters for a situation reasonably as close to reality as possible. Data on lengths, types of terrain and re-use of existing infrastructures will be based on own estimations, see Annex for details.

Also the potential sharing of infrastructures between competitive providers has not been considered. On the one side, the presence of several operators leads to a potential lower utilization of assets per customer, as the customer base is shared among players, and therefore, increases the costs with regard to a monopolistic situation. On the other side, several operators depending on their commercial agreements, or the imposed regulations, can share different combinations of the infrastructures, decreasing the incurred costs per customer. Some implications of sharing infrastructures among operators are briefly considered in the results section.

Next, the model presented in this paper intends to be as agnostic as possible with regard to demand, as it had been pointed out before ${ }^{6}$. However it is required to include some assumptions about it since some of the costs calculations are dependent on the actual number of customers in the network. To simplify the calculations take-up is assumed to represent net additions to the network (therefore including the effect of churn) and it is also assumed that it will happen at $10 \%$ constant rate with regard to the total of potential subscribers. This means that if, for instance, the network is deployed in 4 years, the level of $80 \%$ of the total potential subscribers would be reached in 9.5 years. Once the maximum level of subscribers is attained it will remain indefinitely at that number. Obviously, this is an optimistic scenario for each technology in terms of adoption, but from the perspective of costs is a worstcase scenario. The churn rate will be $20 \%$ of existing customer base or, equivalently, on average each customer changes operator every five years, a figure similar to the existing churn in mobile networks.

To calculate the present value of investments, a weighted average cost of capital (WACC) of $12 \%$ is considered, in

${ }^{5}$ For the interested reader the paper from De Antonio et al (2006) offers some estimation on the capex and opex for building such a backbone network from the scratch, using both a top-down analysis and a bottom-up approximation. For example, considering a case similar to Spain, the backbone network included 8 core routers, 77 service edge routers and 23,000 aggregation devices for the access traffic and the appropriate length of fibre. It was calculated that the investment needed (including the backbone, aggregation and edge sections) amounted to $8.300 \mathrm{M€}$. [14] J. De-Antonio, et al., "A European perspective on the deployment of next generation networks," The Journal of the Communications Network, vol. Vol 5, part 2, pp. 47-55, 2006.

${ }^{6}$ Other potential choice would be to decide that the network is absolutely universal and minimum demand assumptions are made, an approach used for instance in De Antonio et al [14] ibid..

However, this is thought as too unrealistic, leading to increased cost estimations. 
accordance to previous studies ${ }^{7}$ and financial conditions for European broadband operators [7]. The rate of average yearly inflation is estimated at $2 \%$, the objective of the European Central Bank. Operating expenses are calculated just for the 10 first years of operation.

\section{DEPLOYMENT MODEL DESCRIPTION}

As regards the deployment model, it is considered that the network will reach $100 \%$ both of individual and business users ${ }^{8}$ in 10 years. From here it should be noted that potential users are not the same for fixed and mobile technologies. The total number of potential users of fixed networks is 17.9 million. However, only up to $80 \%$ of them will subscribe to a given network, i.e., they will be customers of a particular broadband service offering. The total number of potential users of mobile networks is 53.3 million, representing a $114 \%$ mobile penetration, similar to the latest data available for Spain [15]. Again, only up to $80 \%$ of them will belong to a given network at a certain time and in a certain area.

Three different network models are used in order to calculate the CAPEX and OPEX of wired (FTTH and DOCSIS technology) and wireless technologies that can be deployed, as depicted in Figs 2 to 5, and detailed in the Annex.

The detailed information about ratios and distributions of the distances, as well as the cost of every item involved in the deployment, operation maintenance and management of the networks considered are presented also in the Annex.

The limiting factor for quality in a FTTH-GPON and in a FTTC/VDSL2 deployment is the shared OLT card managing one fibre at the local exchange. For the calculations it has been supposed that each OLT card can manage 2,5 Gb/s per 64 users maximum. It has been also assumed that in FTTC/VDSL $20 \%$ of the users (those very close to it) can be served directly from the local exchange using existing copper wire and without installing any fibre. In the DOCSIS case, the limiting factor for quality is the number of channels shared among customers at the headend. Two implementations have been chosen: the first just the update of the existing network for DOCSIS 3.0 and a new implementation able to offer $50 \mathrm{Mb} / \mathrm{s}$ per user $80 \%$ guaranteed. The figures for this last implementation could be equivalent to a new plant deployment (no re-use of ducts and a ring topology). Finally, the limiting factor for quality in a LTE deployment is the amount of spectrum bandwidth allocated to a single operator. It has been set at $1800 \mathrm{Mb} / \mathrm{s}$ as the maximum total speed available for all users covered by the cell.

${ }^{7}$ This value has been calculated adding the interest rates (around 2 to $3 \%$ ) to a $7-9 \%$ representing investment-related financial and market risks.

${ }^{8}$ For comparison, in the Analysis Mason report for Ofcom the fibre network only reaches $66 \%$ of potential users [7] Analysis Mason, "Competitive models in GPON," Ofcom, London 1st December 2009.

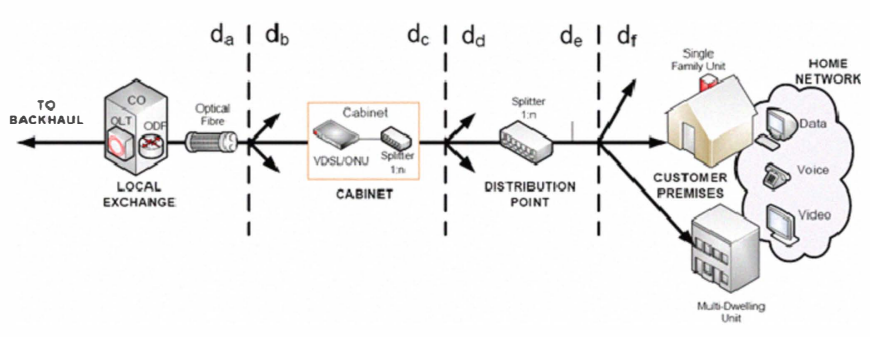

Figure 2. Sections for cost calculations in FTTx

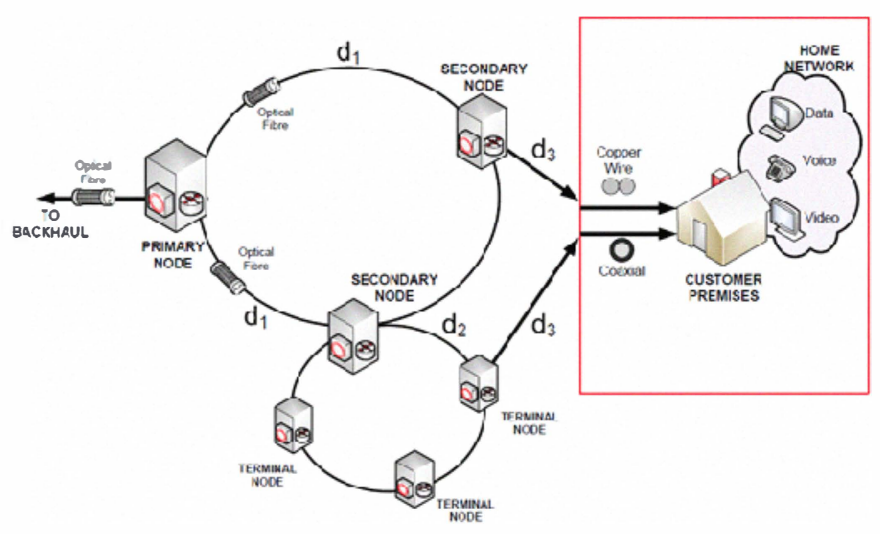

Figure 3. Sections for cost calculations in cable DOCSIS 3.0
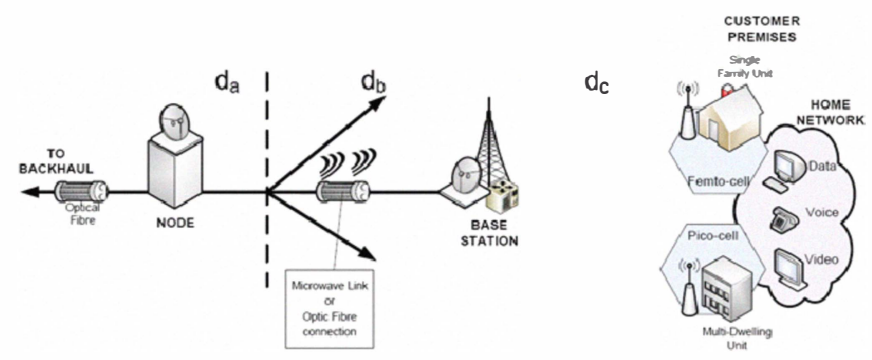

Figure 4. Sections for cost calculations in $4 \mathrm{G}$ mobile communications

All the data for network element costs are supplied by the industry at 2011 prices, either publically or through direct interviews.

\section{RESULTS AND DISCUSSION}

In this section the results of the cost modeling of the different options for a NGAN are presented. All the costs are discounted to give their present value.

\section{A. Capex, opex, total costs and level of investment}

To begin with, the present value of the total capex by areas of maximum 16,384 users and by geotype is shown in Table II. Note that the figures presented are a good approximation to the capital investment required to deploy a neutral operator in a typical municipality of each of the geotypes, re-using existing civil infrastructures where possible. 
TABle II. Present VAlue of Total CAPEX (M€) For ACcess Area (MAX. 16,384 USERS) AND BY GEOTYPE

\begin{tabular}{|c|c|c|c|c|}
\hline \multirow[b]{2}{*}{ Geotype } & \multicolumn{4}{|c|}{ NGAN Technology } \\
\hline & $\begin{array}{l}\text { FTTH } \\
\text { GPON }\end{array}$ & $\begin{array}{l}\text { FTTC } \\
\text { VDSL }\end{array}$ & $\begin{array}{c}\text { HFC } \\
\text { DOCSIS } \\
3.0^{a}\end{array}$ & $\operatorname{LTE}(4 G)^{b}$ \\
\hline $\begin{array}{l}\text { VI (500-100 } \\
\left.\text { inh } / \mathrm{km}^{2}\right)\end{array}$ & 9.44 & 3.89 & 15.67 & 6.40 \\
\hline $\begin{array}{l}\text { VII (100-50 } \\
\left.\text { inh } / \mathrm{km}^{2}\right)\end{array}$ & 1.60 & 0.75 & 3.92 & 1.51 \\
\hline $\begin{array}{l}\text { VIII }(50-10 \\
\left.\text { inh/ } \mathbf{k m}^{2}\right)\end{array}$ & 1.53 & 0.37 & 1.96 & 0.73 \\
\hline $\begin{array}{l}\text { IX } \quad(10-5 \\
\left.\text { inh } / \mathbf{k m}^{2}\right)\end{array}$ & 0.58 & 0.29 & 0.49 & 0.22 \\
\hline $\begin{array}{l}X \\
\left.\text { inh/ } / \mathbf{k m}^{2}\right)\end{array}$ & 0.40 & 0.07 & 0.24 & 0.12 \\
\hline
\end{tabular}

The present value of the total capex by zone is presented in Table III, while the annualized (i.e., divided by the number of years for the roll-out) present value per user is shown in Table IV. This table is provided to supply an easy comparison as a minimum floor with annual ARPU levels. From the figures it can be seen that, rather obviously, the costs increase with lower densities of population. They also show that wireless technologies are more cost-efficient in these lower density areas. On the contrary, it is in the higher density areas where FTTC-VDSL and DOCSIS are the less expensive as they re-use the existing infrastructures. Note that FTTH is the costlier option whatever zone is considered.

Table III. Present Value of Total Capex (M€) by Geotype

\begin{tabular}{|c|c|c|c|c|}
\hline \multirow[b]{2}{*}{ Geotype } & \multicolumn{4}{|c|}{ NGAN Technology } \\
\hline & $\begin{array}{l}\text { FTTH } \\
\text { GPON }\end{array}$ & $\begin{array}{l}\text { FTTC } \\
\text { VDSL }\end{array}$ & $\begin{array}{c}H F C \\
\text { DOCSIS } \\
3.0^{a}\end{array}$ & $\operatorname{LTE}(4 G)^{b}$ \\
\hline $\begin{array}{l}\text { VI (500-100 } \\
\left.\text { inh/ } / \mathbf{k m}^{2}\right)\end{array}$ & 2,298 & 948 & 3,813 & 1,558 \\
\hline $\begin{array}{l}\text { VII (100-50 } \\
\left.\text { inh/ } \mathbf{k m}^{2}\right)\end{array}$ & 518 & 241 & 1,269 & 489 \\
\hline $\begin{array}{l}\text { VIII (50-10 } \\
\left.\text { inh } / \mathbf{k m}^{2}\right)\end{array}$ & 1,356 & 329 & 1,738 & 646 \\
\hline $\begin{array}{l}\text { IX } \quad(10-5 \\
\left.\text { inh/ } / \mathbf{k m}^{2}\right)\end{array}$ & 364 & 184 & 309 & 140 \\
\hline $\begin{array}{l}X \\
\text { inh/km }\end{array}{ }^{(<5}$ & 261 & 49 & 161 & 84 \\
\hline
\end{tabular}

TABle IV. AnNulised Present Value of CAPEX PER User ( $€$ ) By GEOTYPE

\begin{tabular}{|c|c|c|c|c|}
\hline \multirow[b]{2}{*}{ Geotype } & \multicolumn{4}{|c|}{ NGAN Technology } \\
\hline & $\begin{array}{l}\text { FTTH } \\
\text { GPON }\end{array}$ & $\begin{array}{l}\text { FTTC } \\
\text { VDSL }\end{array}$ & $\begin{array}{c}\text { HFC } \\
\text { DOCSIS } \\
3.0^{a}\end{array}$ & $\operatorname{LTE}(4 G)^{b}$ \\
\hline $\begin{array}{l}\text { VI (500-100 } \\
\left.\text { inh } / \mathbf{k m}^{2}\right)\end{array}$ & 576 & 238 & 957 & 391 \\
\hline $\begin{array}{l}\text { VII (100-50 } \\
\left.\text { inh/ } / \mathbf{k m}^{2}\right)\end{array}$ & 390 & 182 & 956 & 369 \\
\hline $\begin{array}{l}\text { VIII (50-10 } \\
\left.\text { inh/ } / \mathbf{k m}^{2}\right)\end{array}$ & 746 & 181 & 956 & 357 \\
\hline $\begin{array}{l}\text { IX } \\
\left.\text { inh/ } / \mathbf{k m}^{2}\right)\end{array}$ & 1,127 & 570 & 957 & 437 \\
\hline $\begin{array}{l}X \\
\text { inh/km }\end{array}{ }^{(<5}$ & 1,554 & 289 & 957 & 482 \\
\hline
\end{tabular}

Another very relevant aspect of comparison among NGAN technologies refers to the cost of guaranteed data rate per user. Usually, when comparing these technologies, this very fundamental perspective is not clearly considered if at all. Table $V$ shows the cost of $10 \mathrm{Mb} / \mathrm{s}$ of guaranteed data rate per user for different NGAN technologies and by geotype. Note that for these calculations, the size of the access area in the case of wireless technologies has had to be reduced, therefore increasing the costs of deployment with regard to above results. Also cable has assumed to be already deployed and only the upgrade to DOCSIS 3.0 is needed.

TABLE V. COST OF 10 MBPS GuARANTEEd DATA RATE PER USER ( $€$ ) BY GEOTYPE (50\% PENETRATION)

\begin{tabular}{|c|c|c|c|c|}
\hline \multirow[b]{2}{*}{ Geotype } & \multicolumn{4}{|c|}{ NGAN Technology } \\
\hline & $\begin{array}{c}\text { FTTH } \\
\text { GPON }^{a}\end{array}$ & $\begin{array}{c}\text { FTTC } \\
\operatorname{VDSL}^{b}\end{array}$ & $\begin{array}{c}H F C \\
\text { DOCSIS } \\
3.0^{c}\end{array}$ & $\operatorname{LTE}(4 G)^{d}$ \\
\hline $\begin{array}{l}\text { VI (500-100 } \\
\left.\text { inh } / \mathrm{km}^{2}\right)\end{array}$ & 1,149 & 632 & 251 & 6,075 \\
\hline $\begin{array}{l}\text { VII }(100-50 \\
\left.\text { inh } / \mathrm{km}^{2}\right)\end{array}$ & 259 & 161 & 84 & 1,901 \\
\hline $\begin{array}{l}\text { VIII (50-10 } \\
\left.\text { inh } / \mathrm{km}^{2}\right)\end{array}$ & 678 & 220 & 114 & 2,508 \\
\hline $\begin{array}{l}\text { IX } \quad(10-5 \\
\left.\text { inh } / \mathrm{km}^{2}\right)\end{array}$ & 182 & 123 & 20 & 550 \\
\hline $\begin{array}{l}X \\
\left.\text { inh } / \mathrm{km}^{2}\right)\end{array}$ & 131 & 32 & 11 & 328 \\
\hline
\end{tabular}

Opex per user for the year 2015 , a year representative of established operations, is shown in Table VI. Opex is dominated by typical operating costs: maintenance, support, billing, etc, in any technology.

TABLE VI. OPEX PER USER (€) FOR THE YEAR 2015

\begin{tabular}{|l|c|c|c|c|}
\hline \multirow{2}{*}{ Geotype } & \multicolumn{4}{|c|}{ NGAN Technology } \\
\cline { 2 - 5 } & $\begin{array}{c}\text { FTTH } \\
\text { GPON }\end{array}$ & $\begin{array}{l}\text { FTTC } \\
\text { VDSL }\end{array}$ & $\begin{array}{c}\text { HFC } \\
\text { DOCSIS } \\
3.0^{\boldsymbol{a}}\end{array}$ & LTE (4G) $^{\boldsymbol{b}}$ \\
\hline Opex per user & 204 & 208 & 218 & 197 \\
\hline $\begin{array}{l}\text { Support, } \\
\text { management } \\
\text { and provision } \\
\text { per user }\end{array}$ & 58 & 75 & 85 & 30 \\
\hline
\end{tabular}

Finally, the present value of the total cost per subscriber by geotype is presented in Table VII.

TABLE VII. ANNUALISED PRESENT VALUe of CAPEX PER USER (€) BY GEOTYPE

\begin{tabular}{|c|c|c|c|c|}
\hline \multirow[b]{2}{*}{ Geotype } & \multicolumn{4}{|c|}{ NGAN Technology } \\
\hline & $\begin{array}{l}\text { FTTH } \\
\text { GPON }\end{array}$ & $\begin{array}{l}\text { FTTC } \\
\text { VDSL }\end{array}$ & $\begin{array}{c}\text { HFC } \\
\text { DOCSIS } \\
3.0^{a}\end{array}$ & $\operatorname{LTE}(4 G)^{b}$ \\
\hline $\begin{array}{l}\text { VI (500-100 } \\
\left.\text { inh } / \mathbf{k m}^{2}\right)\end{array}$ & 826 & 277 & 1,020 & 594 \\
\hline $\begin{array}{l}\text { VII }(100-50 \\
\left.\text { inh } / \mathrm{km}^{2}\right)\end{array}$ & 717 & 222 & 1,022 & 571 \\
\hline $\begin{array}{l}\text { VIII (50-10 } \\
\left.\text { inh } / \mathrm{km}^{2}\right)\end{array}$ & 1,167 & 220 & 1,022 & 558 \\
\hline $\begin{array}{l}\text { IX } \quad(10-5 \\
\left.\text { inh/ } / \mathbf{k m}^{2}\right)\end{array}$ & 1,569 & 610 & 1,023 & 635 \\
\hline
\end{tabular}




\begin{tabular}{|c|c|c|c|c|}
\hline \multirow[b]{2}{*}{ Geotype } & \multicolumn{4}{|c|}{ NGAN Technology } \\
\hline & $\begin{array}{l}\text { FTTH } \\
\text { GPON }\end{array}$ & $\begin{array}{l}\text { FTTC } \\
\text { VDSL }\end{array}$ & $\begin{array}{c}H F C \\
\text { DOCSIS } \\
3.0^{a}\end{array}$ & $\operatorname{LTE}(4 G)^{b}$ \\
\hline $\begin{array}{l}X \\
\text { inh/km²) }\end{array}$ & 1,997 & 328 & 1,026 & 704 \\
\hline
\end{tabular}

\section{B. Sensitivity analysis}

Departing from the base calculations presented in the previous sub-section, Table VIII presents the effects on the costs of several other situations.

TABLE VIII. Sensitivity ANAlysis (\%) OF Present Value of Total Costs

\begin{tabular}{|l|c|c|c|}
\hline \multicolumn{1}{|c|}{ Geotype } & \multicolumn{3}{|c|}{ NGAN Technology } \\
\cline { 2 - 4 } & FTTH GPON & FTTC VDSL & LTE (4G) \\
\hline $\begin{array}{l}\text { Deployment in 5 } \\
\text { years instead of 10 } \\
\text { years }\end{array}$ & $22 \%$ & $16 \%$ & $34 \%$ \\
\hline $\begin{array}{l}\text { Coverage of 80\% } \\
\text { of premises } \\
\text { instead of 100\% }\end{array}$ & $-40 \%$ & $-27 \%$ & $-19 \%$ \\
\hline $\begin{array}{l}\text { Coverage of 60\% } \\
\text { of premises } \\
\text { instead of 100\% }\end{array}$ & $-59 \%$ & $-46 \%$ & $-40 \%$ \\
\hline $\begin{array}{l}\text { Increase of 10 } \\
\text { Mb/s of guranteed } \\
\text { speed per user }\end{array}$ & $1 \%$ & $12 \%$ & $69 \%$ \\
\hline $\begin{array}{l}\text { Increase of } \\
\text { WACC from 12\% } \\
\text { to 15\% }\end{array}$ & $-7 \%$ & $-5 \%$ & $-8 \%$ \\
\hline $\begin{array}{l}\text { Decrease of 30\% } \\
\text { of civil works cost }\end{array}$ & $-22 \%$ & $-11 \%$ & $-14 \%$ \\
\hline $\begin{array}{l}\text { Sharing passive } \\
\text { infrastructures } \\
\text { between } \\
\text { operators 2 }\end{array}$ & $-20 \%$ & $-10 \%$ & $-5 \%$ \\
\hline $\begin{array}{l}\text { Increase of 40 } \\
\text { MHz of allocated } \\
\text { spectrum }\end{array}$ & - & - & $-10 \%$ \\
\hline
\end{tabular}

\section{A DeCAlOGUE OF CONCLUSiONS}

Undoubtedly, the deployment of NGAN is the technical and business element around which the future evolution of the information and technology sector revolves. However, numerous uncertainties remain regarding their development. Some operators have started to invest but maintain their doubts over whether the applications and services offered over a NGAN shall be sufficient to provide a return to investment specially in rural areas and, at present, they are not sure which killer application, if any, will develop to provide sufficiently a new revenue stream for ultra-broadband networks.

In this scenario of uncertainty, more research works are required focusing on the economic, financial and regulatory aspects of NGAN in rural areas. The analysis that has been presented here, although quite simple and rough, allows extracting a few important consequences.

\section{A. Investment, investment, investment}

First, and the datum is not less important despite being expected, it is clear that -any- NGAN requires major investments. Also, and as a consequence, the recovery of these investments implies that the prices charged for access and usage of the services will not differ much of current prices. Every study agrees on this point $[1,4,7,14]$. Thus, it seems probable that the companies interested in deploying NGAN will aim first towards competition in new and attractive offers of services for the users than in prices, since any war of prices entails a reduction of the present and future ARPU.

\section{B. A technology "mix"}

Should the demand for large bandwidths appear, the case could be that no access technology by itself, at least with the technical and economic conditions expected as of today, could present the optimal characteristics for satisfying all the requirements demanded by the users in every circumstance. This has been shown in the model presented where the cheapest technologies per user are those offering the lowest speeds and the contrary being also true. However, the prices per $10 \mathrm{Mb} / \mathrm{s}$ show a different picture. Here, those technologies, such as FTTH, able to supply higher speeds appear as more competitive. They are also the technologies more easily scalable if the target is to increase significantly the speed over the existing infrastructure in some future. Wireless technologies lie in some middle ground: low speeds and intermediate costs.

Therefore, the case of different advantages and drawbacks for each technology, backed by the need to achieve a return on the investments, is leading operators to create platforms capable of integrating different access technologies over the same backbone network. The future market of the information and communications sector, characterised by "comprehensive" operators, would be, in this case, quite different from the current one, where there is a clear separation between technologies. Thus, any -policy, regulatory- measure to facilitate the "mix" of technologies without compromising competition would help to produce the case for the deployment of NGAN.

\section{Distinct departure points and transition paths}

However, the departure point for the different types of operators (historic, cable, wireless, alternative and even new agents) is not the same. These initial differences are conditioning, and shall do so in the future, the path followed for the transformation of their networks into NGAN. The cost calculations carried out support this first impression. As a consequence, each operator will have a different set of drivers for migrating to NGAN [16]. These drivers will dictate their base timeframes for investing in this advanced infrastructure, and subsequently migrating services from existing networks.

\section{Each NGAN is different}

Comparing different types of NGAN from the supply side is a difficult exercise with significant risks. In fact, a careful look into NGAN reveals that there are no easy conclusions.

Data rates are arguably the most tempting parameter for such a comparison. If we take an absolute value such as 50 $\mathrm{Mb} / \mathrm{s}$, not even a currently typical implementation of FTTH will ensure this speed for $100 \%$ of the users all of the time. Therefore, the expected market share and the expected number 
of concurrent users matter to set the real data rate. In particular, cable DOCSIS, due to its "shared-channel" architecture, is a system where the number of concurrent users changes dramatically the maximum speeds available, restricting at times even the meaningfulness of comparisons among implementations of the same technology. But also matters time. Maybe today's implementation of VDSL only reaches $30 \mathrm{Mb} / \mathrm{s}$ at several hundred metres from user premises, but new developments promise to exceed $50 \mathrm{Mb} / \mathrm{s}$ at distances above 1 $\mathrm{Km}$. And not each NGAN addresses the same type -and amount- of users. Wired networks are typically for premises and wireless networks for persons. Therefore wireless systems can serve about three times the subscribers of a fixed network (and enjoy up to triple revenues). At the same time boundaries blur: picocells and femtocells create a convergence where both fibre and radio are needed and no longer is the distinction between technologies valid.

\section{E. Sharing infrastructures}

Sharing infrastructures has already been considered in the regulation, see Ruhle \& Lundborg [17] and it is an area where operators are showing renewed interest. According to the model developed, sharing infrastructures can decrease costs significantly. This is not only important for wired solutions, but for wireless players, where they can achieve higher savings if they go beyond the mere civil works to share some types of active equipment -up to $30 \%$ according to Norman [18]- or even spectrum. Apart from reducing costs, infrastructure sharing can accelerate roll-out, stimulate competition, decrease the troubles of deployment for the public and have environmental benefits (sharing power supplies for instance). There are also some evident risks of collusion.

\section{F. Long life to copper wires}

Copper lines continue to be a strategic asset well into the middle term. Not only are they able to provide right now speeds that would fall into the NGAN category but, in addition, they allow for a smoother and more scalable path in the transition from ADSL to FTTH. Indeed, about $20 \%$ of potential subscribers to a NGAN live close enough to the local exchange so as to be directly provided with a VDSL2 solution from this local exchange and, therefore, requiring just a modest investment in the equipment there. Existing copper -in the part closer to subscriber premises- also allows rolling out FTTC and FFTB solutions to be completed with VDSL2 that could serve as a first step towards a definitive FTTH solution while re-using all fibre deployed so far. Last but not least new developments complemented by fibre could extend the copper capacity well into the $100 \mathrm{Mb} / \mathrm{s}$ range.

\section{G. Cable networks, the key to a competitive landscape}

The upgrade of existing cable networks with DOCSIS 3.0 is, together with VDSL from local exchange, the cheapest alternative for the deployment of NGAN in a country such as Spain. Therefore, cable networks, where they already exist, play a key role in the competitive scenario. Therefore, from the perspective of competition among different providers of NGAN, an interesting solution would be to ensure that, maybe even with some type of public support, the conditions for the cable operators to obtain the required funding are met and they effectively deploy these solutions into the market as soon as possible.

Moreover, cable operators in Spain have a highly relevant asset when taking the perspective of NGAN: according to CMT [19] figures almost $40 \%$ of premises have, in addition to coaxial cabling, a copper wire deployed in parallel with the former. Due to the architecture of cable networks this copper line runs typically for the last $500 \mathrm{~m}$ to user premises. Therefore, there would be possibilities to re-use this copper wire (with VDSL2, for instance) to provide an additional means of deploying NGAN for interested parties.

\section{H. NGAN, wireless solutions and spectrum}

It has not been properly understood yet the role of wireless access technologies as a fundamental part of NGAN. In fact, their use for access from mobile operators it is just a different way to address the same broadband target, but, adding along the road, the mobile advantages: a maybe much more reasonable approach in terms of financing and technology evolution, avoiding the disruptive leaps required in fixed infrastructures. In addition, wireless NGAN are the only scalable solution in terms of infrastructures for areas of low density of population. They are also a complement to NGAN competition in almost any area.

At the same time, it is true that radio-based systems are able to provide today about one tenth of sustained speed compared to wireline solutions and that this difference has been kept constant for the last years. But it is also true that the developments required to improve the capabilities of radiobased systems are at -close- sight: opening of additional spectrum, more efficient spectrum management practices, much smarter radios to access appropriate frequencies at each moment and process signals more efficiently. Therefore, although there is "a limit to the ability of wireless technology to be full players in high-speed Telecom 3.0" [20] and the investments are considerable, there is still room enough for wireless to play a role in medium-speed uses or even higher at low density of population rural areas. As the model shows, 5 $\mathrm{Mb} / \mathrm{s}$ of mobile sustained speed, with much higher peaks depending on the number of concurrent users, and at a cost below that of FTTH could have a significant impact of the NGAN market. This result is coincident with some recent studies. For instance, according to Analysis Mason, terrestrial wireless technology could be used to provide broadband connections to the final $15 \%$ of UK homes not covered by fiber connections. They also acknowledge that the wireless element would be sufficient for households of average usage, after modeling low, medium and high-use scenarios, but only if the number of base stations and spectrum available was increased [21]. Therefore, the usage of spectrum for wireless solutions appears as a main element in configuring the NGAN landscape.

Two are the main relevant parameters for allocation of spectrum to wireless operators: the amount of spectrum (bandwidth) and the band of operation.

The amount of spectrum required per mobile operator depends fundamentally on the level of quality of service, including the number of users concurrently accessing mobile 
data -density of users-, type of usage -more than $90 \%$ of traffic non-voice in 2013 [12], evolution of user perceptions about service quality, and the size of the cell relative to the population density. But also depends on the ability of the mobile transmission technology to manage and re-use frequencies and on the topology and type of the network. In the calculations for the model it was allocated at least $40 \mathrm{MHz}$ of spectrum (already a considerable quantity) to achieve a relatively modest $5 \mathrm{Mb} / \mathrm{s}$ data rate. It is obvious that, maintaining the level of investment, more bandwidth would be required to offer higher speeds to users. Therefore, a significant new quantity of spectrum should be freed up and allocated to operators so as to turn wireless solutions in an actual opportunity. This road is precisely being taken by a number of countries. For instance, the FCC has the ambitious goal to make $500 \mathrm{MHz}$ of spectrum available for mobile broadband over the next 10 years, $300 \mathrm{MHz}$ of them in the next five years. In the case of the EU, the need for spectrum has prompted to adopt a decision aimed at harmonising the allocation of the 790-862 $\mathrm{MHz}$ band spectrum, the well known digital dividend. In addition, the amount of frequency spectrum allocated to an operator has also a direct impact on costs, as it allows delivering more speed per user without decreasing the size of the cell.

The choice of the frequency band for the allocation has a significant impact on costs. For instance, the EU claims that infrastructure equipment for the $800 \mathrm{MHz}$ band was expected to be $70 \%$ cheaper than that required for the radio frequencies in use on $3 \mathrm{G}$ networks. It has also advantages in terms of propagation, since it should provide operators with improved coverage and in-building penetration in comparison with most current $3 \mathrm{G}$ bands. Due to this propagation effects in theory it would look like the lower frequencies of operation saving a significant amount of base stations. But this is only partially true. The limiting factor in a wireless NGAN of the type described in this report is the quality of the service per user, and not the maximum coverage of the cell as a function of the frequency of operation. However, using lower frequencies allows an initial deployment with much less base stations that later could be completed at the same or other frequencies, and it still valid as the best solution for low density areas.

\section{A baseline for the market and for policy action}

The above considerations translate in a baseline for market behaviour. In 2015 it would be relatively possible for Spain to enjoy a "2+" infrastructures-based competition (incumbent, cable operator and mobile operators) for NGAN at about $50 \%$ of premises (i.e., 9 million of households and businesses). Beyond this point the required investments would be much higher. The cheapest choice would be for a " $1+$ " infrastructures-based competition (incumbent using VDSL-type technology and mobile operators) in an additional $10 \%$ of the population, with an added cost for the VDSL of about $400 \mathrm{M} €$. For the rest of the population, the most probable option would be no access to NGAN except maybe some scattered local initiatives and some mobile $4 \mathrm{G}$ deployments in some particular areas, very dependent on the conditions on new spectrum licences. These figures appear lower than the objectives set out in the "Avanza" plan [22]: 70\% of the population with availability of broadband at a $50 \mathrm{Mb} / \mathrm{s}$ speed or higher and $60 \%$ of the population with availability of broadband at a $100 \mathrm{Mb} / \mathrm{s}$ speed or higher. No regulatory "carrot" seems able to easily increase the investment in the required zones, and neither a huge public effort to compensate lack of pure market action seems possible under the current economic conditions.

\section{J. The limits of market action in the rural areas}

In the case of Spain the transition between semi-urban and rural areas happens between zone $\mathrm{V}$ (zones I-V include $57 \%$ of the population and just $1,4 \%$ of the surface) and VI (zones VI$\mathrm{X}$ include the remnant $43 \%$ of the population and $98,6 \%$ of the surface). In other words, the discontinuity in potential profitability appears at the 500 inhabitants $/ \mathrm{km}^{2}$ population density where the figures for capex per user jump well over the $1.000 €$ threshold for any technology, and where the "growth of costs overcomes the growth of the consumption of households in broadband communications" [23].

Thus, as the profitability of this areas depends basically on infrastructure costs, which tend to decrease slowly over time, there are some possibilities of less dense areas to become profitable as time passes by [1]. However, this effect could be too slow and meanwhile it would impact significantly on equity in territorial terms for a potential long period of time.

The picture on the investments required to cover the less dense zones looks rather different when just a small area is considered. Here, because, just one area is considered, it would be possible to deploy a NGAN in a small town or village at an affordable cost, especially if taken into consideration the slow development of the market towards these areas. We could, therefore, be confronted relatively soon with a "patchwork" of local initiatives which try to solve the market failures by their own means.

\section{REFERENCES}

[1] F. Jeanjean, "Financing the next generation infrastructures. Consumer subsidies or infrastructure subsidies?," presented at the EuroCPR 2010, Brussels, 2010.

[2] J. P. R. Pereira, "A cost model for broadband access networks: FTTx versus WiMAX " presented at the Access Networks \& Workshops, 2007. AccessNets '07. Second International Conference on 2007.

[3] M. H. Sherif and Y. Maeda, "Standards for broadband access and beyond," IEEE Communications Magazine, vol. 48, pp. 136 - 138, 2010.

[4] Analysis Mason, "The costs of deploying fibre-based nextgeneration broadband infrastructure," Final report for the Broadband Stakeholder Group, London2008.

[5] S. Forge, et al., "The demand for future mobile communications markets and services in Europe," Institute for Prospective Technological Studies - JRC - EC EUR 21673 EN, 2005.

[6] J. Gomez-Barroso, Robles-Rovalo, A. , "Wireless hopes for universal service in developing countries: an assessment of the Mexican context," info, vol. 10, pp. 83-91, 2008.

[7] Analysis Mason, "Competitive models in GPON," Ofcom, London 1st December 2009.

[8] Ministerio de Vivienda. Atlas estadístico de las áreas urbanas 2006 [Online]. 
http://siu.vivienda.es/portal/index.php?view=article \&catid=19\%3Aatlas-

digital-de-las-reas-urbanas $\&$ id $=57 \% 3$ Aatlas-estadistico-de-las-areas-urbanas2006\&option $=$ com_content\&Itemid $=73 \&$ lang $=$ es

[9] N. Pavlidou, et al., "Power Line Communications: state of the art and future trends," IEEE Communications Magazine, vol. 41, pp. 34-40, 2003.

[10] D. Nerandzic, "Emerging technologies and their implications on regulatory policy," presented at the 17 th Biennial Conference of the International Telecommunications Society "The changing role of the telecommunications industry and the new role for regulation", Montreal, Canada, 2008.

[11] S. Ouvrier, "Driving key technologies for next generation mobile networks," presented at the ICT Mobile Summit 2008, Stockholm, Sweden, 2008.

[12] A. Aguado, "Innovación tecnológica y espectro," Regulatory and economic policy in telecommunications, vol. 2, pp. 41-48, 2009.

[13] S. Ramos, et al., "Next Generation Mobile Network Deployment Strategies," Journal of the Institute of Telecommunications Professionals, vol. 3, pp. 13-19, March 20092009.

[14] J. De-Antonio, et al., "A European perspective on the deployment of next generation networks," The Journal of the Communications Network, vol. Vol 5, part 2, pp. 47-55, 2006.

[15] EC, "Progress report on the single European electronic communications market 2008 (14th report)," E. Commission, Ed., 24/03/2009 ed. Brussels, 2009.

[16] M. N. O. Sadiku and T. H. Nguyen, "Next generation networks," IEEE Potentials, vol. 21, pp. 6-8, Apr.-May 20022002.

[17] E.-O. Ruhle and M. Lundborg, "EU policy for next generation access - an innovative or incremental step forward?," Telecommunications Policy, vol. 34, pp. 36-44, 2010.

[18] T. Norman. (2010, 17 June 2010). Wireless infrastructure sharing saves operators $30 \%$ in capex and $15 \%$ in opex. Available: http://www.analysysmason.com/About-Us/News/Insight/Wireless-

infrastructure-sharing-saves-operators-capex-and-opex/?journey $=117.55$

[19] CMT, "Informe anual 2008," Comisión del Mercado de las Telecomunicaciones, Barcelona2009.

[20] E. Noam, "Regulation 3.0 for telecom 3.0," Telecommunications Policy, vol. 34, pp. 4-10, 2010.

[21] Analysis Mason, "The costs and capabilities of wireless and satellite technologies - A 2016 snapshot," Broadband Stakeholder Group, London26 Oct 20102010.

[22] MITYC, "Plan Avanza 2. Estrategia 2010-2015," Ministerio de Industria, Turismo y Comercio. Secretaría de Estado de Telecomunicaciones y para la Sociedad de la Información, Madrid, España2010.

[23] K. Rupp and S. Selberherr, "The economic limit to Moore's Law," Proceedings of the IEEE, vol. 98, pp. 351-353, 2010.

[24] INE. Censo nacional de población y viviendas 2001 [Online] Available:

http://www.ine.es $/$ jaxi $/$ menu.do?type $=$ pcaxis $\&$ path $=\% 2 \mathrm{Ft} 20 \% 2 \mathrm{Fe} 242 \&$ file $=$ in $\underline{\text { ebase } \& \mathrm{~L}=}$

[25] INE. Directorio central de empresas 2009 [Online]. Available: http://www.ine.es/jaxi/menu.do?type $=$ pcaxis $\&$ path $=\% 2 \mathrm{Ft} 37 \% 2 \mathrm{Fp} 201 \&$ file $=$ in $\underline{\text { ebase } \& \mathrm{~L}=0}$ 
ANNEX - DEMOGRAPHIC DATA

TABLE IX. SUMmARY OF DEMOGRAPHIC DATA FOR SPAIN (2001 FOR POPULATION AND HOUSEHOLDS, 2009 FOR BUSINESSES). SOURCE: INE [24, 25]

\begin{tabular}{|c|c|c|c|c|c|c|c|c|c|c|c|}
\hline Zone & $\mathbf{I}$ & II & III & IV & $\mathbf{v}$ & VI & VII & VIII & IX & $\mathbf{x}$ & \multirow{2}{*}{ Total } \\
\hline Population density & $\begin{array}{l}>10000 \\
\mathrm{hab} / \mathrm{km} 2\end{array}$ & $\begin{array}{l}10-5000 \\
\mathrm{hab} / \mathrm{km} 2\end{array}$ & $\begin{array}{l}5-3000 \\
\mathrm{hab} / \mathrm{km} 2\end{array}$ & $\begin{array}{l}3-1000 \\
\mathrm{hab} / \mathrm{km} 2\end{array}$ & $\begin{array}{c}1000-500 \\
\mathrm{hab} / \mathrm{km} 2\end{array}$ & $\begin{array}{l}500-100 \\
\mathrm{hab} / \mathrm{km} 2\end{array}$ & $\begin{array}{l}100-50 \\
\mathrm{hab} / \mathrm{km} 2\end{array}$ & $\begin{array}{c}50-10 \\
h a b / \mathrm{km} 2\end{array}$ & $\begin{array}{c}10-5 \\
\mathrm{hab} / \mathrm{km} 2\end{array}$ & $<5 \mathrm{hab} / \mathrm{km} 2$ & \\
\hline $\begin{array}{l}\text { Number of } \\
\text { municipalities }\end{array}$ & 17 & 28 & 46 & 175 & 209 & 946 & 745 & 2705 & 1444 & 1797 & 8112 \\
\hline Total population & 2707360 & 6300119 & 3832203 & 8596709 & 5016333 & 11326891 & 3574008 & 4406394 & 668735 & 317055 & 46745807 \\
\hline $\begin{array}{l}\text { Population per } \\
\text { municipality }\end{array}$ & 159256 & 225004 & 83309 & 49124 & 24002 & 11973 & 4797 & 1628 & 463 & 176 & 5763 \\
\hline$\%$ of national population & $5,79 \%$ & $13,48 \%$ & $8,20 \%$ & $18,39 \%$ & $10,73 \%$ & $24,23 \%$ & $7,65 \%$ & $9,43 \%$ & $1,43 \%$ & $0,67 \%$ & $100 \%$ \\
\hline $\begin{array}{l}\% \text { of national population } \\
\text { (accumulated) }\end{array}$ & $5,79 \%$ & $19,27 \%$ & $27,47 \%$ & $45,86 \%$ & $56,59 \%$ & $80,82 \%$ & $88,47 \%$ & $97,90 \%$ & $99,33 \%$ & $100 \%$ & $100 \%$ \\
\hline Total surface $(\mathrm{km} 2)$ & 179,14 & 1086,33 & 969,99 & 5278,55 & 7103,38 & 50561,39 & 52638,58 & 185348,40 & 92937,96 & 108573,47 & 504677,19 \\
\hline Surface per municipality & 10,54 & 38,80 & 21,09 & 30,16 & 33,99 & 53,45 & 70,66 & 68,52 & 64,36 & 60,42 & 62,21 \\
\hline$\%$ of national surface & $0,04 \%$ & $0,22 \%$ & $0,19 \%$ & $1,05 \%$ & $1,41 \%$ & $10,02 \%$ & $10,43 \%$ & $36,73 \%$ & $18,42 \%$ & $21,49 \%$ & $100 \%$ \\
\hline $\begin{array}{l}\text { \% of national surface } \\
\text { (accumulated) }\end{array}$ & $0,04 \%$ & $0,26 \%$ & $0,45 \%$ & $1,50 \%$ & $2,91 \%$ & $12,93 \%$ & $23,36 \%$ & $60,09 \%$ & $78,51 \%$ & $100 \%$ & $100 \%$ \\
\hline $\begin{array}{l}\text { Population density } \\
\text { (inh/ } / \mathrm{km} 2)\end{array}$ & 15113 & 5799 & 3951 & 1629 & 706 & 224 & 67,9 & 23,8 & 7,20 & 2,92 & 92,63 \\
\hline Number of buildings & 150.991 & 349.457 & 292.268 & 1.001 .308 & 768.534 & 2.546 .655 & 1.195 .033 & 2.088 .085 & 517.713 & 374.469 & 9284513 \\
\hline Inhabitants per bulding & 17,93 & 18,03 & 13,11 & 8,59 & 6,53 & 4,45 & 2,99 & 2,11 & 1,29 & 0,85 & 5,03 \\
\hline $\begin{array}{l}\text { Buildings density } \\
(\mathrm{b} / \mathrm{km} 2)\end{array}$ & 842,87 & 321,69 & 301,31 & 189,69 & 108,19 & 50,37 & 22,70 & 11,27 & 5,57 & 3,45 & 18,40 \\
\hline Number of households & 956.677 & 2.076 .924 & 1.170 .050 & 2.509 .817 & 1.406 .991 & 3.106 .774 & 1.056 .207 & 1.486 .870 & 273.065 & 143.794 & 14.187 .169 \\
\hline Persons per household ${ }^{\mathrm{a}}$ & 2,63 & 2,74 & 2,95 & 2,88 & 2,91 & 2,96 & 2,93 & 2,78 & 2,55 & 2,37 & 2,85 \\
\hline Number of businesses ${ }^{b}$ & 247.676 & 536.081 & 311.978 & 709.653 & 400.875 & 880.898 & 270.780 & 330.552 & 50.376 & 24.361 & 3.763.229 \\
\hline $\begin{array}{l}\text { Number of households } \\
\text { and businesses }\left(n_{\text {user }}\right)\end{array}$ & 1.204 .353 & 2.613 .005 & 1.482 .028 & 3.219 .470 & 1.807 .866 & 3.987 .672 & 1.326 .987 & 1.817 .422 & 323.441 & 168.155 & 17.950 .398 \\
\hline $\begin{array}{l}\text { Households and } \\
\text { businesses per building }\end{array}$ & 7,82 & 7,34 & 4,96 & 3,14 & 2,29 & 1,53 & 1,08 & 0,85 & 0,61 & 0,44 & 1,89 \\
\hline Multi-dwelling units & 110.542 & 236.055 & 146.786 & 395.617 & 254.702 & 678.233 & 274.232 & 383.016 & 72.718 & 49.757 & 2.601 .658 \\
\hline$\%$ of total buildings & $73 \%$ & $68 \%$ & $50 \%$ & $39 \%$ & $32 \%$ & $27 \%$ & $23 \%$ & $18 \%$ & $14 \%$ & $13 \%$ & $28 \%$ \\
\hline Single-unit buildings & 40.449 & 113.402 & 145.482 & 614.181 & 542.133 & 1.833 .646 & 921.000 & 1.706 .285 & 442.955 & 323.816 & 6.683 .349 \\
\hline$\%$ of total buildings & $27 \%$ & $32 \%$ & $50 \%$ & $61 \%$ & $68 \%$ & $73 \%$ & $77 \%$ & $82 \%$ & $86 \%$ & $87 \%$ & $72 \%$ \\
\hline
\end{tabular}


TABLE X. NUMBER OF POTENTIAL SUBSCRIBERS TO NGAN AS A FUNCTION OF GEOTYPE. SOURCE: OWN ESTIMATIONS FROM INE [24, 25] AND MINISTERIO DE VIVIENDA [8]

\begin{tabular}{|l|c|c|c|}
\hline \multicolumn{1}{|c|}{ Geotype } & $\begin{array}{c}\text { Total potential } \\
\text { subscribers } \\
\text { (households }+ \\
\text { businesses) }\end{array}$ & Total population & $\begin{array}{c}\text { \% of potential } \\
\text { subscribers and } \\
\text { population per } \\
\text { zone a/b }\end{array}$ \\
\hline VIa $\left(500-100 \mathrm{inh} / \mathrm{km}^{2}\right)$ & 1.232 .210 & 3.500 .065 & $31 \%$ \\
\hline VIb $\left(500-100 \mathrm{inh} / \mathrm{km}^{2}\right)$ & 2.755 .461 & 7.826 .826 & $69 \%$ \\
\hline VIIa $\left(100-50 \mathrm{inh} / \mathrm{km}^{2}\right)$ & 741.787 & 1.997 .873 & $56 \%$ \\
\hline VIIb $\left(100-50 \mathrm{inh} / \mathrm{km}^{2}\right)$ & 585.200 & 1.576 .135 & $44 \%$ \\
\hline VIIIa $\left(50-10 \mathrm{inh} / \mathrm{km}^{2}\right)$ & 790.356 & 1.916 .242 & $43 \%$ \\
\hline VIIIb $\left(50-10 \mathrm{inh} / \mathrm{km}^{2}\right)$ & 1.027 .066 & 2.490 .152 & $57 \%$ \\
\hline IX $\left(10-5 \mathrm{inh} / \mathrm{km}^{2}\right)$ & 323.441 & 668.735 & $100 \%$ \\
\hline $\mathrm{X}\left(<5 \mathrm{inh} / \mathrm{km}^{2}\right)$ & 168.155 & 317.055 & $100 \%$ \\
\hline
\end{tabular}


TABLE XI. NUMBER OF POTENTIAL USERS (PREMISES) PER ACCESS AREA, SPLITTER RATIO AND NUMBER OF FIBRES, DIVISION POINT, CABINETS AND DISTRIBUTION BOXES PER GEOTYPE

\begin{tabular}{|c|c|c|c|c|c|c|c|c|c|c|c|}
\hline Zone & $\begin{array}{c}\text { Number of } \\
\text { users per } \\
\text { access area } \\
\left(\mathrm{n}_{\text {area }}\right) \\
\end{array}$ & $\begin{array}{c}\text { Minimum } \\
\text { number of } \\
\text { fibres at the } \\
\text { exchange } \\
\left(\mathrm{n}_{\text {fibre }}\right)\end{array}$ & $\begin{array}{c}\text { Total splitter } \\
\text { ratio }\left(\mathbf{r}_{\text {split }}\right. \\
\left.=\mathbf{r}_{\text {split1 }} \mathbf{x} \mathbf{r}_{\text {split2 }}\right)\end{array}$ & $\begin{array}{c}\text { Number of } \\
\text { fibres at each } \\
\text { A segment } \\
\left(\mathrm{n}_{\text {fibreA }}\right)\end{array}$ & $\begin{array}{c}\text { Number of } \\
\text { division points } \\
\text { at } A-B\left(n_{\text {divaB }}\right)\end{array}$ & $\begin{array}{c}\text { Number of } \\
\text { fibres at each } \\
\text { B segment } \\
\left(\mathbf{n}_{\text {fibreB }}\right) \\
\end{array}$ & $\begin{array}{c}\text { Number of } \\
\text { cabinets }\left(\mathrm{n}_{\text {cab }}\right)\end{array}$ & $\begin{array}{c}\text { Number of } \\
\text { fibres at each } \\
\text { C segment } \\
\left(\mathrm{n}_{\text {fibrec }}\right)\end{array}$ & $\begin{array}{c}\text { Number of } \\
\text { division points } \\
\text { at C-D }\left(\mathrm{n}_{\text {divCD }}\right)\end{array}$ & $\begin{array}{c}\text { Number of } \\
\text { fibres at each } \\
\text { D segment } \\
\left(\mathrm{n}_{\text {fibreb }}\right)\end{array}$ & $\begin{array}{l}\text { Number of } \\
\text { distribution } \\
\text { boxes }\left(\mathrm{n}_{\text {box }}\right)\end{array}$ \\
\hline $\begin{array}{l}\text { VI } \quad(500-100 \\
\left.\text { inh } / \mathbf{k m}^{2}\right)\end{array}$ & 16384 & 256 & $8 \times 8$ & $96(\min 64)$ & 4 & $16(\min 8)$ & 32 & $96(\min 64)$ & 32 & $16(\min 6)$ & 342 \\
\hline $\begin{array}{l}\text { VII (100-50 } \\
\left.\text { inh/ } \mathbf{k m}^{2}\right)\end{array}$ & 4096 & 64 & $8 \times 8$ & $24(\min 16)$ & 4 & $8(\min 4)$ & 16 & $48(\min 32)$ & 16 & $16(\min 6)$ & 86 \\
\hline $\begin{array}{l}\text { VIII (50-10 } \\
\left.\text { inh/ } / \mathrm{km}^{2}\right)\end{array}$ & 2048 & 32 & $8 \times 8$ & $16(\min 8)$ & 4 & $8(\min 2)$ & 16 & $24(\min 16)$ & 16 & $16(\min 6)$ & 43 \\
\hline $\begin{array}{l}\text { IX } \\
\left.\text { inh/ } \mathrm{km}^{2}\right)\end{array}$ & 512 & 8 & $1 \times 8$ & $16(\min 2)$ & 4 & $3(\min 2)$ & 4 & $24(\min 16)$ & 4 & $16(\min 6)$ & 11 \\
\hline $\begin{array}{ll}\mathrm{X} & (<5 \\
\left.\text { inh/ } \mathbf{k m}^{2}\right) & \\
\end{array}$ & 256 & 8 & $1 \times 4$ & $16(\min 2)$ & 4 & $3(\min 2)$ & 4 & $16(\min 6)$ & 4 & $16(\min 6)$ & 11 \\
\hline
\end{tabular}

TABLE XII. NUMBER OF POTENTIAL SUBSCRIBERS PER ZONE AND CELL AREA AND NUMBER OF BASE STATIONS FOR WIRELESS ACCESS PER GEOTYPE

\begin{tabular}{|c|c|c|c|c|c|c|c|c|c|}
\hline Zone & $\begin{array}{c}\text { Total number } \\
\text { of potential } \\
\text { subscribers } \\
\text { per zone } \\
\left(n_{z o n e}\right) \\
\end{array}$ & $\begin{array}{c}\text { Number of } \\
\text { users per cell } \\
\text { area }\left(n_{\text {eell }}\right)\end{array}$ & $\begin{array}{c}\text { Average } \\
\text { radius of cell } \\
\text { area }(m)\left(d_{c}\right)\end{array}$ & $\begin{array}{c}\text { Number of } \\
\text { base stations } \\
\text { per zone }\end{array}$ & $\begin{array}{c}\text { Number of } \\
\text { users per } \\
\text { access area } \\
\left(n_{\text {areen }}\right)\end{array}$ & $\begin{array}{c}\text { Number of } \\
\text { base stations } \\
\text { per equivalent } \\
\text { access area } \\
\left(n_{b .}\right) \\
\end{array}$ & $\begin{array}{c}\text { Number of } \\
\text { fibres at each } \\
\text { B segment } \\
\left(n_{\text {fibreB }}\right)\end{array}$ & $\begin{array}{c}\text { Number of } \\
\text { division points } \\
\text { at } A-B \text { per } \\
\text { access area } \\
\left(n_{\text {divAB }}\right) \\
\end{array}$ & $\begin{array}{c}\text { Number of } \\
\text { fibres at each } \\
\text { A segment } \\
\left(n_{\text {fibreA }}\right)\end{array}$ \\
\hline $\begin{array}{l}\text { VI } \quad(\mathbf{5 0 0 - 1 0 0} \\
\left.\text { inh } / \mathbf{k m}^{2}\right)\end{array}$ & 3.987 .672 & 360 & 1205 & 11.077 & 16384 & 46 & $8(\min 2)$ & 8 & 16 \\
\hline $\begin{array}{l}\text { VII (100-50 } \\
\left.\text { inh/ } / \mathbf{k m}^{2}\right)\end{array}$ & 1.326 .987 & 360 & 2132 & 3.686 & 4096 & 12 & $8(\min 2)$ & 8 & 16 \\
\hline $\begin{array}{l}\text { VIII (50-10 } \\
\left.\text { inh/ } / \mathbf{k m}^{2}\right)\end{array}$ & 1.817 .422 & 360 & 3419 & 5.048 & 2048 & 6 & $8(\min 2)$ & 4 & 16 \\
\hline$\underset{\left.\text { inh } / \mathrm{km}^{2}\right)}{(10-5}$ & 323.441 & 223 & 4516 & 1.450 & 512 & 1 & $8(\min 2)$ & - & 16 \\
\hline $\begin{array}{ll}X & (<5 \\
\left.\text { inh/ } / \mathbf{k m}^{2}\right)\end{array}$ & 168.155 & 106 & 4668 & 1.586 & 256 & 1 & $8(\min 2)$ & - & 16 \\
\hline
\end{tabular}


TABLE XIII. TYPES OF TERRAIN IN WIRED ACCESS AS A FUNCTION OF THE GEOTYPE

\begin{tabular}{|c|c|c|c|c|c|c|}
\hline Geotype & $\begin{array}{l}\text { Fraction } d_{a} d_{d} \\
\quad \operatorname{road}(\%)\end{array}$ & $\begin{array}{l}\text { Fraction } d_{a} d_{d} \\
\text { footpath(\%) }\end{array}$ & $\begin{array}{c}\text { Fraction } d_{a} d_{d} \\
\text { soft (\%) }\end{array}$ & $\begin{array}{c}\text { Fraction } d_{e}-d_{f} \\
\text { footpath }(\%)\end{array}$ & $\begin{array}{c}\text { Fraction } d_{e}-d_{f} \\
\text { soft }(\%)\end{array}$ & $\begin{array}{c}\text { Fraction } d_{e}-d_{f} \\
\text { aerial (\%) }\end{array}$ \\
\hline $\begin{array}{l}\text { VIa }(500-100 \\
\left.\text { inh } / \mathrm{km}^{2}\right)\end{array}$ & 5 & 75 & 20 & 55 & 25 & 20 \\
\hline $\begin{array}{l}\text { VIb }(500-100 \\
\left.\mathrm{inh} / \mathrm{km}^{2}\right)\end{array}$ & 5 & 75 & 20 & 55 & 25 & 20 \\
\hline $\begin{array}{l}\text { VIIa }(100-50 \\
\left.\text { inh } / \mathrm{km}^{2}\right)\end{array}$ & 5 & 45 & 50 & 40 & 30 & 30 \\
\hline $\begin{array}{l}\text { VIIb }(100-50 \\
\left.\text { inh } / \mathrm{km}^{2}\right)\end{array}$ & 5 & 45 & 50 & 40 & 30 & 30 \\
\hline $\begin{array}{l}\text { VIIIa }(50-10 \\
\left.\mathrm{inh} / \mathrm{km}^{2}\right)\end{array}$ & 5 & 35 & 60 & 35 & 25 & 40 \\
\hline $\begin{array}{l}\text { VIIIb }(50-10 \\
\left.\text { inh } / \mathrm{km}^{2}\right)\end{array}$ & 5 & 35 & 60 & 35 & 25 & 40 \\
\hline $\begin{array}{l}\text { IX }(10-5 \\
\left.\text { inh } / \mathrm{km}^{2}\right)\end{array}$ & 5 & 25 & 70 & 30 & 20 & 50 \\
\hline $\mathrm{X}\left(<5 \mathrm{inh} / \mathrm{km}^{2}\right)$ & 5 & 25 & 70 & 25 & 15 & 60 \\
\hline
\end{tabular}

TABLE XIV. AVERAGE DISTANCES IN WIRED ACCESS AS A FUNCTION OF THE GEOTYPE

\begin{tabular}{|c|c|c|c|c|c|c|}
\hline Geotype & $\boldsymbol{d}_{a}(\boldsymbol{m})$ & $\boldsymbol{d}_{b}(\boldsymbol{m})$ & $\boldsymbol{d}_{c}(\boldsymbol{m})$ & $\boldsymbol{d}_{\boldsymbol{d}}(\boldsymbol{m})$ & $\boldsymbol{d}_{e}(\boldsymbol{m})$ & $\boldsymbol{d}_{f}(\boldsymbol{m})$ \\
\hline VIa $\left(500-100 \mathrm{inh} / \mathrm{km}^{2}\right)$ & 100 & 250 & 300 & 50 & 10 & 10 \\
\hline VIb $\left(500-100 \mathrm{inh} / \mathrm{km}^{2}\right)$ & 500 & 1500 & 500 & 100 & 20 & 30 \\
\hline VIIa $\left(100-50 \mathrm{inh} / \mathrm{km}^{2}\right)$ & 50 & 200 & 200 & 40 & 10 & 10 \\
\hline VIIb $\left(100-50 \mathrm{inh} / \mathrm{km}^{2}\right)$ & 250 & 1000 & 1000 & 200 & 30 & 70 \\
\hline VIIIa $\left(50-10 \mathrm{inh} / \mathrm{km}^{2}\right)$ & 50 & 150 & 350 & 60 & 10 & 15 \\
\hline VIIIb $\left(50-10 \mathrm{inh} / \mathrm{km}^{2}\right)$ & 200 & 500 & 1000 & 200 & 30 & 100 \\
\hline IX $\left(10-5 \mathrm{inh} / \mathrm{km}^{2}\right)$ & 100 & 300 & 800 & 120 & 20 & 60 \\
\hline X $\left(<5 \mathrm{inh} / \mathrm{km}^{2}\right)$ & 100 & 300 & 800 & 120 & 20 & 60 \\
\hline
\end{tabular}

TABLE XV. WORKS, PASSIVE AND ACTIVEEQUIPMENT COSTS FOR WIRED NGAN

\begin{tabular}{|c|c|c|c|}
\hline Cost category & Price $(\boldsymbol{\epsilon})$ & $\begin{array}{c}\text { Yearly } \\
\text { evolution }\end{array}$ & Comments \\
\hline \multicolumn{4}{|l|}{ Civil works } \\
\hline Duct deployment (road) $\left(\mathrm{c}_{\text {duct-r }}\right)$ & $\begin{array}{c}70 \text { (per } \\
\mathrm{m} \text { ) }\end{array}$ & $\begin{array}{l}\text { Inflation } \\
\text { increase }\end{array}$ & Average of conventional trenching and microtrenching. For any technology \\
\hline Duct deployment (footpath) ( $\left.\mathrm{c}_{\text {duct-f }}\right)$ & $\begin{array}{c}50 \text { (per } \\
\mathrm{m})\end{array}$ & $\begin{array}{l}\text { Inflation } \\
\text { increase }\end{array}$ & idem \\
\hline Duct deployment (soft ground) ( $\mathrm{c}_{\text {duct-sg }}$ ) & $\begin{array}{c}30 \text { (per } \\
\mathrm{m})\end{array}$ & $\begin{array}{l}\text { Inflation } \\
\text { increase }\end{array}$ & idem \\
\hline Aerial deployment $\left(\mathrm{c}_{\text {duct-aer }}\right)$ & $\begin{array}{c}8 \text { (per } \\
\mathrm{m})\end{array}$ & $\begin{array}{l}\text { Inflation } \\
\text { increase }\end{array}$ & No ducts are required. For any technology \\
\hline Sub-duct deployment $\left(\mathrm{c}_{\text {sduct }}\right)$ & $\begin{array}{c}1,5 \text { (per } \\
\mathrm{m})\end{array}$ & $\begin{array}{l}\text { Inflation } \\
\text { increase }\end{array}$ & $\begin{array}{l}\text { Relevant for any operator, alternative in particular, when inserting sub-duct in existing } \\
\text { ducts. For any technology }\end{array}$ \\
\hline Cable installation $\left(\mathrm{c}_{\text {cinst }}\right)$ & $\begin{array}{l}10 \text { (per } \\
\mathrm{m})\end{array}$ & $\begin{array}{l}\text { Inflation } \\
\text { increase }\end{array}$ & For any type of cable and any type of duct and aerial installations. For any technology \\
\hline Exchange cabinet $\left(\mathrm{c}_{\mathrm{cab}-\mathrm{e}}\right)$ & 3600 & $5 \%$ fall & Able to accommodate ODF, splitter, ONU and xDSL equipment \\
\hline
\end{tabular}




\begin{tabular}{|c|c|c|c|}
\hline Cost category & Price $(\boldsymbol{\epsilon})$ & $\begin{array}{c}\text { Yearly } \\
\text { evolution }\end{array}$ & Comments \\
\hline Division point $\left(\mathrm{c}_{\mathrm{div}}\right)$ & 600 & $5 \%$ fall & $\begin{array}{l}\text { For separation of fibres/cables at a-b and c-d segments. Includes fibre fusion and boxes } \\
\text { as required }\end{array}$ \\
\hline Field (street) cabinet $\left(\mathrm{c}_{\mathrm{cab}}\right)$ & 23000 & $2 \%$ fall & $\begin{array}{l}\text { Able to accommodate ODF, MDF, power unit, AC/DC converter, batteries and xDSL } \\
\text { equipment. }\end{array}$ \\
\hline Distribution point boxes $\left(c_{b o x}\right)$ & 2500 & $2 \%$ fall & $\begin{array}{l}\text { Outdoor cabinet for last mile FTTH GPON splitters. Up to } 48 \text { subscribers per } \\
\text { boxAverage price. }\end{array}$ \\
\hline Distribution point boxes $\left(\mathrm{c}_{\mathrm{box}}\right)$ & 250 & $2 \%$ fall & Average price. Only $10 \%$ require upgrading for FTTC/B/VDSL \\
\hline In-building wiring $\left(\mathrm{c}_{\mathrm{mdw}}\right)$ & 200 & $5 \%$ fall & Per premise. Only for FTTH technology and multi-dwelling units. \\
\hline \multicolumn{4}{|l|}{ Passive equipment } \\
\hline Fibre cable $\left(\mathrm{c}_{\text {fibre }}\right) 96 \mathrm{FO}$ & $\begin{array}{l}6,5(\text { per } \\
\mathrm{m})\end{array}$ & $3 \%$ fall & \\
\hline Fibre cable $\left(\mathrm{c}_{\text {fibre }}\right) 16 \mathrm{FO}$ & $\begin{array}{l}2(\text { per } \\
\text { m) }\end{array}$ & $3 \%$ fall & \\
\hline Fibre cable ( $\left.\mathrm{c}_{\text {fibre }}\right) 8 \mathrm{FO}$ & $\begin{array}{l}1,3(\text { per } \\
\mathrm{m})\end{array}$ & $3 \%$ fall & \\
\hline Copper cable & 0 & - & Existing copper does not need to be upgraded \\
\hline Migration of existing copper lines $\left(\mathrm{c}_{\text {mig }}\right)$ & 20 & $\begin{array}{l}\text { Inflation } \\
\text { increase }\end{array}$ & Per line. For FTTC/B/xDSL technologies \\
\hline GPON splitter ( $\left.\mathrm{c}_{\text {split }}\right)$ & 120 & $5 \%$ fall & $\begin{array}{l}\text { The maximum split ratio is } 64 \text { (max number of users per fibre). The split ratio of an } \\
\text { individual splitter is } 8 \text { (therefore, two stages are required) }\end{array}$ \\
\hline $\begin{array}{l}\text { Optical Distribution Frame (ODF) at } \\
\text { local exchange }\left(\mathrm{c}_{\mathrm{ODF}}\right)\end{array}$ & 2800 & $5 \%$ fall & Holding up to 256 fibres (and therefore up to $64 \times 256$ max number of customers) \\
\hline $\begin{array}{l}\text { Optical Network Unit (ONU) at cabinet } \\
\left(\mathrm{c}_{\mathrm{ONU}}\right)\end{array}$ & 1000 & $5 \%$ fall & $\begin{array}{c}\text { Holding } 64 \text { fibres (and therefore } 64 \times 64 \text { max number of customers). Only used if } \\
\text { competition takes place from the cabinet }\end{array}$ \\
\hline \multicolumn{4}{|l|}{ Active equipment } \\
\hline $\begin{array}{l}\text { Optical Line Termination (OLT) card at } \\
\text { local exchange }\left(\mathrm{c}_{\mathrm{OLT}}\right)\end{array}$ & 30000 & $10 \%$ fall & Each card holds 640 users ( 10 ports at 64 users per port) \\
\hline $\begin{array}{l}\text { Aggregation switch at local exchange } \\
\left(\mathrm{c}_{\text {switch }}\right)\end{array}$ & 3000 & $10 \%$ fall & $10 \mathrm{~Gb} / \mathrm{s}$ of switching capacity per OLT card (640 users) \\
\hline $\begin{array}{l}\text { Mini-VDSLAM at cabinet or } \\
\text { distribution point box }\left(\mathrm{c}_{\mathrm{VDSL}}\right)\end{array}$ & 2000 & $10 \%$ fall & Each supports 64 users. For FTTC/B/xDSL technologies \\
\hline Battery for VDSL at cabinet $\left(\mathrm{c}_{\text {batt }}\right)$ & 1000 & $5 \%$ fall & For FTTC/B/xDSL technologies \\
\hline
\end{tabular}

TABLE XVI. FRACTION OF PREMISES IN MULTI-DWELLING UNITS AND AVERAGE NUMBER OF PREMISES PER BUILDING AS A FUNCTION OF THE GEOTYPE. SOURCE: OWN ESTIMATIONS

\begin{tabular}{|l|c|c|}
\hline Geotypes & $\begin{array}{c}\text { Fraction of premises in multi- } \\
\text { dwelling units (frmdw) }\end{array}$ & $\begin{array}{c}\text { Average premises } \\
\text { per building }\end{array}$ \\
\hline VIa $\left(500-100 \mathrm{inh} / \mathrm{km}^{2}\right)$ & 40 & 2,32 \\
\hline VIb $\left(500-100 \mathrm{inh} / \mathrm{km}^{2}\right)$ & 30 & 2,75 \\
\hline VIIa $\left(100-50 \mathrm{inh} / \mathrm{km}^{2}\right)$ & 30 & 1,28 \\
\hline VIIb $\left(100-50 \mathrm{inh} / \mathrm{km}^{2}\right)$ & 20 & 1,42 \\
\hline VIIIa $\left(50-10 \mathrm{inh} / \mathrm{km}^{2}\right)$ & 20 & 1,08 \\
\hline VIIIb $\left(50-10 \mathrm{inh} / \mathrm{km}^{2}\right)$ & 10 & 1,00 \\
\hline IX $\left(10-5 \mathrm{inh} / \mathrm{km}^{2}\right)$ & 10 & 1,00 \\
\hline
\end{tabular}




\begin{tabular}{|l|c|c|}
\hline Geotypes & $\begin{array}{c}\text { Fraction of premises in multi- } \\
\text { dwelling units (frmdw) }\end{array}$ & $\begin{array}{c}\text { Average premises } \\
\text { per building }\end{array}$ \\
\hline $\mathrm{X}\left(<5 \mathrm{inh} / \mathrm{km}^{2}\right)$ & 5 & 1,00 \\
\hline
\end{tabular}

TABLE XVII. Percentage of DUCt Re-USE (FR) AS A FUnCtion OF THE Geotype

\begin{tabular}{|l|c|c|c|}
\hline Geotype & $\boldsymbol{d}_{\boldsymbol{a}}-\boldsymbol{d}_{\boldsymbol{b}}(\%)$ & $\boldsymbol{d}_{\boldsymbol{c}}-\boldsymbol{d}_{\boldsymbol{d}}(\%)$ & $\boldsymbol{d}_{\boldsymbol{e}}-\boldsymbol{d}_{f}(\%)$ \\
\hline VIa $\left(500-100 \mathrm{inh} / \mathrm{km}^{2}\right)$ & 60 & 40 & 30 \\
\hline VIb $\left(500-100 \mathrm{inh} / \mathrm{km}^{2}\right)$ & 40 & 20 & 10 \\
\hline VIIa $\left(100-50 \mathrm{inh} / \mathrm{km}^{2}\right)$ & 60 & 40 & 30 \\
\hline VIIb $\left(100-50 \mathrm{inh} / \mathrm{km}^{2}\right)$ & 40 & 20 & 10 \\
\hline VIIIa $\left(50-10 \mathrm{inh} / \mathrm{km}^{2}\right)$ & 40 & 20 & 10 \\
\hline VIIIb $\left(50-10 \mathrm{inh} / \mathrm{km}^{2}\right)$ & 40 & 20 & 10 \\
\hline IX $\left(10-5 \mathrm{inh} / \mathrm{km}^{2}\right)$ & 40 & 20 & 10 \\
\hline X $\left(<5 \mathrm{inh} / \mathrm{km}^{2}\right)$ & 40 & 20 & 10 \\
\hline
\end{tabular}

TABLE XVIII. NUMBER OF POTENTIAL SUBSCRIBERS FOR NEW CABLE NETWORK AS A FUNCTION OF THE GEOTYPE

\begin{tabular}{|l|c|c|c|}
\hline \multicolumn{1}{|c|}{ Geotype } & $\begin{array}{c}\text { Total potential subscribers (households }+ \\
\text { businesses) }\end{array}$ & $\begin{array}{c}\text { \%of potential subscribers covered with } \\
\text { cable network }\end{array}$ & $\begin{array}{c}\text { Potential subscribers for new cable } \\
\text { network built }\end{array}$ \\
\hline $\begin{array}{l}\text { VIa }(500-100 \\
\text { inh/km })\end{array}$ & 1.232 .210 & $52 \%$ & 591.461 \\
\hline $\begin{array}{l}\text { VIb }(500-100 \\
\text { inh/km })\end{array}$ & 2.755 .461 & $53 \%$ & 1.295 .067 \\
\hline $\begin{array}{l}\text { VIIa }(100-50 \\
\text { inh/km })\end{array}$ & 741.787 & $25 \%$ & 556.340 \\
\hline $\begin{array}{l}\text { VIIb }(100-50 \\
\text { inh/km })\end{array}$ & 585.200 & $25 \%$ & 438.900 \\
\hline $\begin{array}{l}\text { VIIIa }(50-10 \\
\left.\text { inh } / \mathrm{km}^{2}\right)\end{array}$ & 790.356 & $25 \%$ & 592.767 \\
\hline $\begin{array}{l}\text { VIIIb }(50-10 \\
\left.\text { inh } / \mathrm{km}^{2}\right)\end{array}$ & 1.027 .066 & $18 \%$ & 842.194 \\
\hline IX $\left(10-5 \mathrm{inh} / \mathrm{km}^{2}\right)$ & 323.441 & $17 \%$ & 268.456 \\
\hline X $\left(<5 \mathrm{inh} / \mathrm{km}^{2}\right)$ & 168.155 & $0 \%$ & 168.155 \\
\hline
\end{tabular}

TABLE XIX. PASSIVE AND ACTIVE DoCSIS EQUIPMENT COSTS

\begin{tabular}{|c|c|c|c|}
\hline Cost category & $\begin{array}{c}\text { Price } \\
(\boldsymbol{\epsilon})\end{array}$ & $\begin{array}{c}\text { Yearly } \\
\text { evolution }\end{array}$ & Comments \\
\hline $\begin{array}{l}\text { EdgeQUAM modulator VOD (CEQUAMVOD \& } \\
\text { BTV) }\end{array}$ & 29000 & $7 \%$ fall & $\begin{array}{l}144 \text { Channels for Video on demand and Broadcast TV services, capacity is } \\
\text { excepted to be increased significantly in coming years }\end{array}$ \\
\hline Docsis 3.0, CMTS (C_CMTS) & 519000 & $12 \%$ fall & Docsis 3.0, Full node CMTS in primary node \\
\hline $\begin{array}{l}\text { Optical Distribution Frame (ODF) at Primary } \\
\text { Node in HFC networks (cODF) }\end{array}$ & 2800 & $5 \%$ fall & Holding up to 256 fibres \\
\hline RF combiner $\left(C_{-}\right.$RF combi) & 250 & $5 \%$ fall & RF combiner/splitter .- HFC Combination \\
\hline BONT cabinet in PN (C CABN_NP ) & & & BONT cabinet in primary node \\
\hline Power node (C_NPOT) & 75000 & $5 \%$ fall & $\begin{array}{l}\text { Power distribution node supply \& installation as main power source in } \\
\text { outdoor cabinets }\end{array}$ \\
\hline Secondary node(C Cab_NS ) & 9250 & $5 \%$ fall & $\begin{array}{l}\text { cabinet with } \mathrm{HFC} \text { O/E BONT, ODF, and primary coax distribution point in } \\
\text { secondary node }\end{array}$ \\
\hline
\end{tabular}




\begin{tabular}{|c|c|c|c|}
\hline Cost category & $\begin{array}{c}\text { Price } \\
(\boldsymbol{\epsilon})\end{array}$ & $\begin{array}{c}\text { Yearly } \\
\text { evolution }\end{array}$ & Comments \\
\hline Terminal node (C_cab_NT) & 9250 & $5 \%$ fall & $\begin{array}{l}\text { cabinet with HFC O/E BONT, ODF, and primary coax distribution point in } \\
\text { terminal node }\end{array}$ \\
\hline Coax Amplification (C_AMPLI) & 70 & $2 \%$ fall & HFC Coax Amplification in last mile \\
\hline Connection to power utility urban (C_power 1$)$ & 2500 & $\begin{array}{l}\text { Inflaction } \\
\text { Increase }\end{array}$ & $\begin{array}{l}\text { Connection to power utility company in Urban areas, for outdoor Secondary \& } \\
\text { Terminal Nodes }\end{array}$ \\
\hline $\begin{array}{l}\text { Connection to power utility low dense } \\
\text { (C_power1) }\end{array}$ & 12500 & $\begin{array}{l}\text { Inflaction } \\
\text { Increase }\end{array}$ & Connection to power utility company in non urban areas \\
\hline CATV trunk 2-way tap (C_TAP2) & 3,7 & $2 \%$ fall & $\begin{array}{l}\text { Outdoor CATV sub-trunk 2-way taps, are used in last mille Drop, so highly } \\
\text { needed in cable networks }\end{array}$ \\
\hline CATV trunk 4-way tap (C_TAP4) & 4,1 & $2 \%$ fall & Outdoor CATV sub-trunk 4-way taps \\
\hline CATV trunk 4-way tap (C_TAP8) & 5,8 & $2 \%$ fall & Outdoor CATV sub-trunk 8-way taps \\
\hline Coax Cable QR540 (C_coax QR540) & 5,1 & $3 \%$ fall & Coax Cable QR540 in mts, final drop cable \\
\hline Coax Cable RG6 (C_coax QR540) & 5,1 & $2 \%$ fall & Coax Cable RG6 in mts, distribution cable in final drop \\
\hline
\end{tabular}

TABLE XX. DEPLOYMENT COSTS FOR WIRELESS NGAN

\begin{tabular}{|c|c|c|c|}
\hline Cost category & Price $(\boldsymbol{E})$ & Yearly evolution & Comments \\
\hline \multicolumn{4}{|l|}{ Civil works } \\
\hline Base station deployment $\left(\mathrm{c}_{\mathrm{bs}_{\mathrm{s}-\mathrm{d}}}\right)$ & 30.000 & $5 \%$ fall & Per site. For any technology \\
\hline \multicolumn{4}{|l|}{ Spectrum } \\
\hline Spectrum fees at $800 \mathrm{MHz}\left(\mathrm{c}_{\text {spect }}\right)$ & 20.000 .000 & Inflation increase & Per MHz. 20 years license. \\
\hline Spectrum fees at $2,6 \mathrm{GHz}\left(\mathrm{c}_{\text {spect }}\right)$ & 2.000 .000 & Inflation increase & Per MHz. 20 years license. \\
\hline Administrative licensing & $3.500 €$ & & Per site \\
\hline \multicolumn{4}{|l|}{ Active equipment } \\
\hline Base station at $2,6 \mathrm{GHz}\left(\mathrm{c}_{\mathrm{bs}}\right)$ & 23.000 & $10 \%$ fall & For LTE. 3 sectors, $20 \mathrm{MHz}$ each \\
\hline Base station at $800 \mathrm{MHz}\left(\mathrm{c}_{\mathrm{bs}}\right)$ & 18.000 & $10 \%$ fall & For LTE. 3 sectors, $20 \mathrm{MHz}$ each \\
\hline Tr-Rx equipment $\left(c_{t r}\right)$ & 4.000 & $10 \%$ fall & For LTE. 2 Tr-Rx per sector \\
\hline Power supply equipment for base station $\left(\mathrm{c}_{\text {pow }}\right)$ & 10.000 & $5 \%$ fall & For any technology \\
\hline Pico-cell $\left(\mathrm{c}_{\text {pico }}\right)$ & 350 & $10 \%$ fall & Up to 8 users. For any technology \\
\hline Femtocell $\left(\mathrm{c}_{\mathrm{femto}}\right)$ & 250 & $10 \%$ fall & For any technology \\
\hline
\end{tabular}

TABLE XXI. OPERATING COSTS FOR WIRED NGAN

\begin{tabular}{|c|c|c|c|}
\hline Cost category & $\begin{array}{l}\text { Price } \\
(\boldsymbol{\epsilon})\end{array}$ & $\begin{array}{c}\text { Yearly } \\
\text { evolution }\end{array}$ & Comments \\
\hline \multicolumn{4}{|l|}{ Civil works } \\
\hline Duct rental & $\begin{array}{l}2 \text { (per } \\
\mathrm{m})\end{array}$ & $\begin{array}{l}\text { Inflation } \\
\text { increase }\end{array}$ & Only relevant for alternative operators \\
\hline \multicolumn{4}{|l|}{ Passive equipment } \\
\hline $\begin{array}{l}\text { Installation of final drop } \\
\left(c_{\text {drop }}\right)\end{array}$ & 120 & $\begin{array}{l}\text { Inflation } \\
\text { increase }\end{array}$ & $\begin{array}{l}\text { Per user. Incurred only when a customer takes a service. Includes the faceplate at subscriber premises. } \\
\text { For any technology }\end{array}$ \\
\hline $\begin{array}{l}\text { Migration due to churn } \\
\left(\mathrm{c}_{\text {chumn }}\right)\end{array}$ & 100 & $\begin{array}{l}\text { Inflation } \\
\text { increase }\end{array}$ & $\begin{array}{l}\text { Average value per churned user. It could vary as a function of the access point / unbundling } \\
\text { possibilities (at exchange, at cabinet or at distribution box). Includes internal and external migration } \\
\text { costs. For any technology }\end{array}$ \\
\hline $\begin{array}{l}\text { Accomodation of } \\
\text { equipment in the exchange }\end{array}$ & 10 & $\begin{array}{l}\text { Inflation } \\
\text { increase }\end{array}$ & Per user. Only relevant for alternative operators \\
\hline
\end{tabular}




\begin{tabular}{|c|c|c|c|}
\hline Cost category & $\begin{array}{l}\text { Price } \\
(\boldsymbol{\epsilon})\end{array}$ & $\begin{array}{c}\text { Yearly } \\
\text { evolution }\end{array}$ & Comments \\
\hline \multicolumn{4}{|l|}{ Active equipment } \\
\hline $\begin{array}{l}\text { Customer Premises } \\
\text { Equipment }(\mathrm{CPE})\left(\mathrm{c}_{\mathrm{CPE}}\right)\end{array}$ & 100 & $10 \%$ fall & Per user. Including modem, routing and wireless hub. For any technology. Cost per 5 years. \\
\hline Battery backup ( $\left.\mathrm{c}_{\text {batt }}\right)$ & 100 & $10 \%$ fall & $\begin{array}{l}\text { Per user. For FTTH as this technology does not include power supply on the wire. Includes } \\
\text { maintenance. Cost per } 5 \text { years. }\end{array}$ \\
\hline $\begin{array}{l}\text { Power consumption at } \\
\text { exchange }\left(\mathrm{c}_{\text {pow }}\right)\end{array}$ & 2 & $\begin{array}{l}\text { Inflation } \\
\text { increase }\end{array}$ & $\begin{array}{l}\text { Per line. Considers the average of a fixed and a variable per KWh charge (30 W consumption per OLT } \\
\text { port). }\end{array}$ \\
\hline \multicolumn{4}{|l|}{ Support and management } \\
\hline $\begin{array}{l}\text { Network support (FTTH) } \\
\left(\mathrm{c}_{\text {nets }}\right)\end{array}$ & 6 & $\begin{array}{l}\text { Inflation } \\
\text { increase }\end{array}$ & Per line \\
\hline $\begin{array}{l}\text { Network support } \\
\text { (FTTC/VDSL) }\left(\mathrm{c}_{\text {nets }}\right)\end{array}$ & 12 & $\begin{array}{l}\text { Inflation } \\
\text { increase }\end{array}$ & Per line \\
\hline $\begin{array}{l}\text { General support (FTTH) } \\
\left(\mathrm{c}_{\text {gens }}\right)\end{array}$ & 9 & $\begin{array}{l}\text { Inflation } \\
\text { increase }\end{array}$ & Per line \\
\hline $\begin{array}{l}\text { General support } \\
\left.\text { (FTTC/VDSL) ( } \text { c }_{\text {gens }}\right)\end{array}$ & 12 & $\begin{array}{l}\text { Inflation } \\
\text { increase }\end{array}$ & Per line \\
\hline General management $\left(\mathrm{c}_{\text {genm }}\right)$ & 13 & $\begin{array}{l}\text { Inflation } \\
\text { increase }\end{array}$ & Per line. For any tecnology \\
\hline Finance and billing $\left(\mathrm{c}_{\mathrm{bill}}\right)$ & 1 & $\begin{array}{l}\text { Inflation } \\
\text { increase }\end{array}$ & Per line. For any technology \\
\hline $\begin{array}{l}\text { Bad debts and other costs } \\
\left(c_{\text {bad }}\right)\end{array}$ & 3 & $\begin{array}{l}\text { Inflation } \\
\text { increase }\end{array}$ & Per line. For any technology \\
\hline $\begin{array}{l}\text { Provision / maintenance } \\
(\text { FTTH })\left(\mathrm{c}_{\text {prov }}\right)\end{array}$ & 4 & $\begin{array}{l}\text { Inflation } \\
\text { increase }\end{array}$ & Per line \\
\hline $\begin{array}{l}\text { Provision / maintenance } \\
\text { (FTTC/VDSL) }\left(\mathrm{c}_{\text {prov }}\right)\end{array}$ & 12 & $\begin{array}{l}\text { Inflation } \\
\text { increase }\end{array}$ & Per line \\
\hline
\end{tabular}

TABLE XXII. SUMMARY OF OPERATING COSTS FOR WIRELESS NGAN

\begin{tabular}{|c|c|c|c|}
\hline Cost category & Comments & Price (€ & $\begin{array}{l}\text { Yearly } \\
\text { evolution }\end{array}$ \\
\hline \multicolumn{4}{|l|}{ Civil works } \\
\hline Duct rental & Only relevant for alternative operators & $2($ per $m)$ & $\begin{array}{l}\text { Inflation } \\
\text { increase }\end{array}$ \\
\hline Site rental & Per site & $6.000 €$ & $\begin{array}{l}\text { Inflation } \\
\text { increase }\end{array}$ \\
\hline \multicolumn{4}{|l|}{ Passive equipment } \\
\hline Installation of final drop ( $\left.\mathrm{c}_{\mathrm{drop}}\right)$ & $\begin{array}{l}\text { Per user. Incurred only when a customer takes a service. Includes the faceplate at subscriber } \\
\text { premises. For any technology }\end{array}$ & 120 & $\begin{array}{l}\text { Inflation } \\
\text { increase }\end{array}$ \\
\hline Migration due to churn ( $\left.\mathrm{c}_{\text {chum }}\right)$ & $\begin{array}{l}\text { Average value per churned user. It could vary as a function of the access point / unbundling } \\
\text { possibilities (at exchange, at cabinet or at distribution box). Includes internal and external } \\
\text { migration costs. For any technology }\end{array}$ & 100 & $\begin{array}{l}\text { Inflation } \\
\text { increase }\end{array}$ \\
\hline $\begin{array}{l}\text { Accommodation of equipment } \\
\text { in the exchange }\end{array}$ & Per user. Only relevant for alternative operators & 10 & $\begin{array}{l}\text { Inflation } \\
\text { increase }\end{array}$ \\
\hline \multicolumn{4}{|l|}{ Active equipment } \\
\hline $\begin{array}{l}\text { Femto and Pico-cells power } \\
\text { consumption }\end{array}$ & Considerations about the power consumption on the cells reception equipment & 120 & \\
\hline
\end{tabular}




\begin{tabular}{|c|c|c|c|}
\hline Cost category & Comments & Price $(\epsilon$ & $\begin{array}{c}\text { Yearly } \\
\text { evolution }\end{array}$ \\
\hline $\begin{array}{l}\text { Femto and Pico-cells } \\
\text { equipment technical } \\
\text { maintenance }\end{array}$ & For example: Replacement of equipment due to malfunction & 60 & \\
\hline Tx-Rx power consumption & & 80 & $\begin{array}{l}\text { Inflation } \\
\text { increase }\end{array}$ \\
\hline $\begin{array}{l}\text { Tx-Rx equipment technical } \\
\text { maintenance }\end{array}$ & & 30 & $\begin{array}{l}\text { Inflation } \\
\text { increase }\end{array}$ \\
\hline Base Station power supply & Per site & 1.200 & $\begin{array}{l}\text { Inflation } \\
\text { increase }\end{array}$ \\
\hline $\begin{array}{l}\text { Base Station equipment } \\
\text { technical maintenance }\end{array}$ & Per site & 600 & $\begin{array}{l}\text { Inflation } \\
\text { increase }\end{array}$ \\
\hline Sanctions & Per year for the whole network & 3.000 .000 & $\begin{array}{c}20 \% \\
\text { increase }\end{array}$ \\
\hline Closures and withdrawals & Per year for the whole network & 15.000 .000 & $\begin{array}{c}10 \% \\
\text { increase }\end{array}$ \\
\hline Adaptations & 1 of 30 base stations need this type of work a year & 1.000 & $\begin{array}{l}\text { Inflation } \\
\text { increase }\end{array}$ \\
\hline \multicolumn{4}{|l|}{ Support and management } \\
\hline $\begin{array}{l}\text { General management and } \\
\text { support }\left(\mathrm{c}_{\text {genn }}\right)\end{array}$ & For any technology & 25 & $\begin{array}{l}\text { Inflation } \\
\text { increase }\end{array}$ \\
\hline Finance and billing $\left(\mathrm{c}_{\mathrm{bill}}\right)$ & For any technology & 1 & $\begin{array}{l}\text { Inflation } \\
\text { increase }\end{array}$ \\
\hline Bad debts and other costs $\left(\mathrm{c}_{\mathrm{bad}}\right)$ & For any technology. Include the debts, churn, & 3 & $\begin{array}{l}\text { Inflation } \\
\text { increase }\end{array}$ \\
\hline
\end{tabular}

